\title{
Review Article \\ Radix Bupleuri: A Review of Traditional Uses, Botany, Phytochemistry, Pharmacology, and Toxicology
}

\author{
Fude Yang, ${ }^{1}$ Xiaoxv Dong, ${ }^{2}$ Xingbin Yin, ${ }^{2}$ Wenping Wang, ${ }^{2}$ Longtai You, ${ }^{2}$ and Jian $\mathrm{Ni}^{1,2}$ \\ ${ }^{1}$ Gansu University of Chinese Medicine, Lanzhou 730000, China \\ ${ }^{2}$ School of Chinese Materia Medica, Beijing University of Chinese Medicine, Beijing 100102, China \\ Correspondence should be addressed to Jian Ni; njtcm@263.net
}

Received 14 February 2017; Accepted 20 April 2017; Published 16 May 2017

Academic Editor: Gail B. Mahady

Copyright (c) 2017 Fude Yang et al. This is an open access article distributed under the Creative Commons Attribution License, which permits unrestricted use, distribution, and reproduction in any medium, provided the original work is properly cited.

Radix Bupleuri (Chaihu) has been used as a traditional medicine for more than 2000 years in China, Japan, Korea, and other Asian countries. Phytochemical studies demonstrated that this plant contains essential oils, triterpenoid saponins, polyacetylenes, flavonoids, lignans, fatty acids, and sterols. Crude extracts and pure compounds isolated from Radix Bupleuri exhibited various biological activities, such as anti-inflammatory, anticancer, antipyretic, antimicrobial, antiviral, hepatoprotective, neuroprotective, and immunomodulatory effects. However, Radix Bupleuri could also lead to hepatotoxicity, particularly in high doses and with long-term use. Pharmacokinetic studies have demonstrated that the major bioactive compounds (saikosaponins a, b , c, and d) were absorbed rapidly in rats after oral administration of the extract of Radix Bupleuri. This review aims to comprehensively summarize the traditional uses, botany, phytochemistry, pharmacology, toxicology, and pharmacokinetics of Radix Bupleuri reported to date with an emphasis on its biological properties and mechanisms of action.

\section{Introduction}

Radix Bupleuri, also called "Chaihu" in Chinese, is derived from the dried roots of Bupleurum chinense DC. and Bupleurum scorzonerifolium Willd. [1]. As a traditional herbal medicine, Radix Bupleuri has been used widely for the treatments of influenza, fever, inflammation, malaria, menstrual disorders, and hepatitis in China, Japan, Korea, and other Asian countries [2,3]. According to ancient Chinese medical literatures, Radix Bupleuri is capable of regulating the exterior and interior metabolisms, dispersing evil heat from the superficies, soothing the liver, and promoting yang and qi (representing "life energy" or "life force" in TCM theories). In recent decades, investigations of Radix Bupleuri have focused on its biological activities, including its anti-inflammatory [4, 5], anticancer [6,7], antipyretic [8], antimicrobial [9], antiviral [10], hepatoprotective [11], and immunomodulatory effects [12]. In addition, Radix Bupleuri also exhibited significant effects on membrane fluidity [13]. These studies have resulted in the isolation of essential oils, triterpenoid saponins, polyacetylenes, flavonoids, lignans, fatty acids, and sterols from this plant [14]. Among them, triterpenoid saponins are known to be the major bioactive compounds $[15,16]$. Saikosaponins a and d are commonly used as chemical standards for quality evaluation of Radix Bupleuri in the current Chinese Pharmacopoeia and recent publications. However, an increasing number of recently published studies have reported adverse effects of Radix Bupleuri. The purpose of this review is to provide updated, comprehensive information on the traditional uses, botany, phytochemistry, pharmacology, toxicology, and pharmacokinetics of Radix Bupleuri based on scientific literatures in the past few decades. This study will facilitate exploring the therapeutic potential of this plant and evaluate future research opportunities.

\section{Traditional Uses}

Radix Bupleuri, which is characterized by a wide spectrum of biological and pharmacological effects, has been used as a famous traditional Chinese medicinal herb with a history of medical use in China. According to TCM theory, Radix Bupleuri is thought to regulate the exterior and interior 
metabolisms, disperse evil heat from superficies, sooth the liver, and promote yang and qi [1]. Radix Bupleuri was initially recorded in Shennong Bencao Jing, a famous monograph of traditional Chinese medicine written in China in $200 \mathrm{AD}$ [17]. According to a record of traditional Chinese medicine dated 2000 years ago, Radix Bupleuri had mainly been used for the treatment of mouth-bitterness, throat-drying, and eyes-dazzling. In other monographs of Materia Medica, such as Jin Kui Yao Lue, Kaibao Bencao, Bencao Gangmu, and Xinbian Bencao, this plant was described to be used for the treatment of common cold with fever, influenza, hepatitis, malaria, menoxenia, and hyperlipidemia [18]. Currently, Radix Bupleuri exerts other pharmacological effects, such as balancing different organs and energies within the body, strengthening the action of the digestive tract, improving liver and circulatory system function, and relieving liver tension [19]. Therefore, it is also used as a popular tonic herb in China. In Korea and Japan, this plant is commonly used for the treatment of fever, pain, and inflammation associated with influenza and the common cold [20]. In addition, this plant is also used as analgesics in the treatment of distending pain in the hypochondriac region of the chest and against amenorrhoea.

Radix Bupleuri is combined with other herbs in many classical formulas to improve clinical effect. Xiaoyaosan (XYS), a well-known formula for relieving depression, is originated from the book of "Taiping Huimin Heji Jufang" in Song Dynasty (960-1279 AD), consisting of Radix Bupleuri, Radix Angelicae Sinensis, Radix Paeoniae Alba, Rhizoma Atractylodis Macrocephalae, Poria, Radix Glycyrrhizae, Herba Menthae, and Rhizoma Zingiberis Recens. XYS exerts various pharmacological effects, including soothing the liver and improving the circulation of qi to relieve depression. Furthermore, it has been commonly recognized as a safe and effective prescription in the treatment of depressive disorder [21-23]. The 2015 edition of the Chinese Pharmacopoeia lists 97 Chinese patent medicines containing Radix Bupleuri, and the compatible herbs that are more frequently described include Radix Glycyrrhizae, Rhizoma Zingiberis Recens, Radix Scutellariae, and Panax ginseng. Table 1 lists subsets of the Chinese patent drugs containing Radix Bupleuri in different formulations. Although Radix Bupleuri has been used to treat certain diseases in ethnomedicines for thousands of years, this herbal medicine should be comprehensively understood and recent information should be obtained for its clinical use.

\section{Botanical Characterization and Distribution}

According to the Chinese pharmacopoeia, Radix Bupleuri is derived from the dried roots of Bupleurum chinense DC. and Bupleurum scorzonerifolium Willd. (Figure 1). The former is known as "Beichaihu" (Northern Chinese Thorowax Root) and the latter is known as "Nanchaihu" (Southern Chinese Thorowax Root), due to the difference of the origin and description. The drug is collected in spring or autumn, removed from the aerial part and soil, and dried.

Beichaihu. As a herbaceous perennial plant, Bupleurum chinense DC. grows to the height of $50-85 \mathrm{~cm}$. Its root is conical, taupe, and approximately $6-20 \mathrm{~cm}$ in length. Its stems are erect, tufted, and apex branched. The leaves are alternate; the leaf blades are broadly linear-lanceolate, $4-7 \times 0.6-0.8 \mathrm{~cm}$ in size; the apex is acuminate. Compound umbels are axillary and terminal, approximately $1-4 \mathrm{~cm}$ in length; the bracts are 0 or $2-3$, linear; the petals are 5 and bright yellow. The fruits are oblong, brown, and approximately $3 \mathrm{~mm}$ in length. They blossom from July to September and fruit from August to October. This plant is widely cultivated in China, Japan, and Korea. Moreover, it grows in grasslands, stream banks, sunny slopes and roadsides, and other locations with altitudes of 100-2700 m [24].

Nanchaihu. Bupleurum scorzonerifolium Willd. is a herbaceous perennial plant and approximately $30-60 \mathrm{~cm}$ high. Its root is flexuose, reddish brown, and approximately $4-10 \mathrm{~cm}$ in length. Its stems are 1-3, usually glabrous, and apex branched. The leaf blades are linear or linear-lanceolate, 6-16 $\times 0.2-0.7 \mathrm{~cm}$ in size; the apex is acuminate. Compound umbels are axillary and terminal; the bracts are 1-3; the petals are 5 and yellow. The fruits are ellipsoid, dark brown, approximately $2-3 \mathrm{~mm}$ in length. They blossom from July to August and fruit from August to October. This plant is also widely cultivated in East Asian countries, such as China, Japan, and Korea. It grows in shrub forest margins, sunny mountain slopes, dry grasslands, and other locations with altitudes of 200-3000 m [24].

There were approximately 36 Bupleurum species and varieties in different districts and markets due to the slightly different morphologic appearance of Bupleurum plants, including $B$. longiradiatum Turcz. with toxic ingredients and B. hamiltonii Balak with very little active constituents [25, 26]. Inevitably, this situation will compromise the values of Radix Bupleuri and even imperil the safety of the consumers. Until now, several techniques have been developed to identify and distinguish them, including TLC [27], HPLC [28-30], HPLC-ELSD [31, 32], HPLC-MS [33, 34], UPLC-MS [35], and capillary electrochromatography [36]. Among these methods mentioned above, HPLC-ELSD is the most commonly used analytical method for evaluating the quality and authenticity of Radix Bupleuri. The total amounts of saikosaponins a and $\mathrm{d}$ are used as the indicator compounds to characterize the quality of this plant with minimum contents of $0.3 \%$ in the Pharmacopoeia of People's Republic of China.

\section{Chemical Constituents}

In the past few decades, approximately 74 compounds have been isolated from Radix Bupleuri, including essential oils, triterpenoid saponins, polyacetylenes, flavonoids, lignans, fatty acids, and sterols. Triterpenoid saponins, flavonoids, and essential oil, which possess multiple pharmacological activities, are considered as the main active ingredients of Radix Bupleuri. Their structures are shown in (Table 2) (Figures 2-6).

4.1. Volatile Compounds (Essential Oils). The essential oils of Radix Bupleuri are regarded as one of the most important 
TABLE 1: The traditional and clinical uses of Radix Bupleuri in China.

\begin{tabular}{|c|c|c|}
\hline Preparation name & Compositions & Traditional uses \\
\hline $\begin{array}{l}\text { Xiao Chai Hu } \\
\text { decoction }\end{array}$ & $\begin{array}{l}\text { Radix Bupleuri, Radix Scutellariae, Panax ginseng, } \\
\text { Pinellia ternata, Radix Glycyrrhizae, Rhizoma } \\
\text { Zingiberis Recens, Fructus jujubae. }\end{array}$ & $\begin{array}{l}\text { Curing thoracic and hypochondrium fullness, } \\
\text { mouth-bitterness, throat-drying, and eyes-dazzling }\end{array}$ \\
\hline $\begin{array}{l}\text { Da Chai Hu } \\
\text { decoction }\end{array}$ & $\begin{array}{l}\text { Radix Bupleuri, Radix Scutellariae, Pinellia ternata, } \\
\text { Rhizoma Zingiberis Recens, Fructus jujubae, Fructus } \\
\text { Aurantii immaturus, Radix Paeoniae Alba, Rheum } \\
\text { palmatum. }\end{array}$ & Treating diarrhea or constipation \\
\hline $\begin{array}{l}\text { Chaihu Guizhi } \\
\text { decoction }\end{array}$ & $\begin{array}{l}\text { Radix Bupleuri, Radix Scutellariae, Panax ginseng, } \\
\text { Pinellia ternata, Radix Glycyrrhizae, Rhizoma } \\
\text { Zingiberis Recens, Fructus jujubae, Radix Paeoniae } \\
\text { Alba, Ramulus cinnamomi. }\end{array}$ & $\begin{array}{l}\text { Curing fever with cold aversion, restless arthralgia of } \\
\text { limbs, and epigastric induration }\end{array}$ \\
\hline $\begin{array}{l}\text { Chaihu Guizhi } \\
\text { Ganjiang decoction }\end{array}$ & $\begin{array}{l}\text { Radix Bupleuri, Ramulus cinnamomi, Rhizoma } \\
\text { Zingiberis, Radix Scutellariae, Radix Glycyrrhizae, } \\
\text { Trichosanthes kirilowii, Ostreae Concha. }\end{array}$ & $\begin{array}{l}\text { Curing palpitation, fullness of the upper abdomen, and } \\
\text { a bitter taste in the mouth }\end{array}$ \\
\hline $\begin{array}{l}\text { Chaihu plus } \\
\text { Mangxiao decoction }\end{array}$ & $\begin{array}{l}\text { Radix Bupleuri, Radix Scutellariae, Panax ginseng, } \\
\text { Pinellia ternata, Radix Glycyrrhizae, Rhizoma } \\
\text { Zingiberis Recens, Fructus jujubae, Natrii Sulfas. }\end{array}$ & $\begin{array}{l}\text { Curing thoracic and hypochondrium fullness, retching } \\
\text { counterflow, hot flashes, mouth-bitterness, } \\
\text { throat-drying, eyes-dazzling, and constipation }\end{array}$ \\
\hline $\begin{array}{l}\text { Chaihu plus Longgu } \\
\text { Muli decoction }\end{array}$ & $\begin{array}{l}\text { Radix Bupleuri, Radix Scutellariae, Panax ginseng, } \\
\text { Pinellia ternata, Rhizoma Zingiberis Recens, Fructus } \\
\text { jujubae, Rheum palmatum, Ramulus cinnamomi, } \\
\text { Ostreae Concha, Os Draconis, Poria cocos, Minium. }\end{array}$ & $\begin{array}{l}\text { Curing thoracic and hypochondrium fullness, difficulty } \\
\text { in micturition, and delirium }\end{array}$ \\
\hline $\begin{array}{l}\text { Buzhong Yiqi } \\
\text { decoction }\end{array}$ & $\begin{array}{l}\text { Radix Astragali, Radix Bupleuri, Panax ginseng, Radix } \\
\text { Glycyrrhizae, Rhizoma Cimicifugae, Radix Angelicae } \\
\text { sinensis, Atractylodis Macrocephalae Rhizoma, Citri } \\
\text { Reticulatae Pericarpium. }\end{array}$ & $\begin{array}{l}\text { Curing prolapse of uterus, prolapse of rectum, uterine } \\
\text { bleeding, shortness of breath and tiredness, and pale } \\
\text { tongue }\end{array}$ \\
\hline Chaige Jieji decoction & $\begin{array}{l}\text { Radix Bupleuri, Radix Puerariae lobatae, Radix } \\
\text { Glycyrrhizae, Radix Scutellariae, Rhizoma et Radix } \\
\text { Notopterygii, Radix Angelicae dahuricae, Radix } \\
\text { Paeoniae Alba, Radix Platycodonis, Gypsum fibrosum, } \\
\text { Rhizoma Zingiberis Recens, Fructus jujubae. }\end{array}$ & $\begin{array}{l}\text { Curing mind-cold due to exogenous evils, headache, } \\
\text { and vexation and sleeplessness }\end{array}$ \\
\hline Zheng Chaihu Yin & $\begin{array}{l}\text { Radix Bupleuri, Pericarpium Citri Reticulatae, Radix } \\
\text { Saposhnikovia, Radix Paeoniae Rubra, Radix } \\
\text { Glycyrrhizae, Rhizoma Zingiberis Recens. }\end{array}$ & $\begin{array}{l}\text { Curing mind-cold due to exogenous evils, fever with } \\
\text { chilliness, headache, and body pain }\end{array}$ \\
\hline $\begin{array}{l}\text { Xuefu Zhuyu } \\
\text { decoction }\end{array}$ & $\begin{array}{l}\text { Radix Angelicae sinensis, Radix Rehmanniae, Semen } \\
\text { Persicae, Flos Carthami, Fructus Aurantii, Radix } \\
\text { Bupleuri, Radix Glycyrrhizae, Radix Platycodonis, } \\
\text { Rhizoma Chuanxiong, Radix Achyranthis Bidentatae, } \\
\text { Radix Paeoniae Rubra }\end{array}$ & $\begin{array}{l}\text { Treating blood pressure related symptoms caused by qi } \\
\text { stagnation and blood stasis syndrome }\end{array}$ \\
\hline Shengxian Decoction & $\begin{array}{l}\text { Radix Astragali, Radix Bupleuri, Rhizoma } \\
\text { Anemarrhenae, Radix Platycodonis, Rhizoma } \\
\text { Cimicifugae. }\end{array}$ & $\begin{array}{l}\text { Curing coronary heart disease, chronic congestive heart } \\
\text { failure, vital myocarditis, and myocardial ischemia }\end{array}$ \\
\hline Xiaoyao san & $\begin{array}{l}\text { Radix Bupleuri, Radix Angelicae Sinensis, Radix } \\
\text { Paeoniae Alba, Rhizoma Atractylodis Macrocephalae, } \\
\text { Poria, Radix Glycyrrhizae, Herba Menthae, and } \\
\text { Rhizoma Zingiberis Recens. }\end{array}$ & $\begin{array}{l}\text { Soothing the liver and improving the circulation of qi to } \\
\text { relieve depression }\end{array}$ \\
\hline Chaihu Shugan San & $\begin{array}{l}\text { Radix Bupleuri, Fructus Aurantii, Rhizoma } \\
\text { Chuanxiong, Rhizoma Cyperi, Pericarpium Citri } \\
\text { Reticulatae, Radix Paeoniae Rubra, Radix Glycyrrhizae. }\end{array}$ & Curing neurologic impairment, and depression \\
\hline Sini San & $\begin{array}{l}\text { Radix Bupleuri, Fructus Aurantii, Radix Paeoniae } \\
\text { Rubra, Radix Glycyrrhizae. }\end{array}$ & $\begin{array}{l}\text { Curing insomnia, liver injury, hepatitis, chronic stress } \\
\text { model, and palmoplantar hidrosis }\end{array}$ \\
\hline Tongqi San & $\begin{array}{l}\text { Radix Bupleuri, Rhizoma Cyperi, Rhizoma } \\
\text { Chuanxiong. }\end{array}$ & Curing deafness, tinnitus, and stagnation of liver qi \\
\hline Danzhi Xiaoyao San & $\begin{array}{l}\text { Radix Bupleuri, Radix Angelicae Sinensis, Radix } \\
\text { Paeoniae Alba, Rhizoma Atractylodis Macrocephalae, } \\
\text { Poria, Cortex Moutan, Fructus Gardeniae. }\end{array}$ & $\begin{array}{l}\text { Curing headache, menoxenia, distending pain in the } \\
\text { lower abdomen, and depression }\end{array}$ \\
\hline
\end{tabular}


TABle 1: Continued.

\begin{tabular}{|c|c|c|}
\hline Preparation name & Compositions & Traditional uses \\
\hline Yigan Yiqi Jieyu Keli & $\begin{array}{l}\text { Radix Bupleuri, Fructus Aurantii, Radix Paeoniae Alba, } \\
\text { Radix et Rhizoma Salviae miltiorrhizae, Radix } \\
\text { Astragali, Radix Codonopsis, Ramulus cinnamomi, } \\
\text { Poria, Acanthopanax senticosus (Rupr. et Maxim) } \\
\text { Harms, Fructus trichosanthis, Rhizoma Pinelliae } \\
\text { Preparatum, and others. }\end{array}$ & $\begin{array}{l}\text { Curing chronic hepatitis, hypochondriac pain, bloating, } \\
\text { and lassitude }\end{array}$ \\
\hline Xiao' er Tuire Keli & $\begin{array}{l}\text { Radix Bupleuri, Folium isatidis, Radix Isatidis, Flos } \\
\text { Lonicerae Japonicae, Cortex Moutan, Cape Jasmine } \\
\text { Fruit, Radix Scutellariae, Herba Lophatheri, Pheretima, } \\
\text { Rhizoma paridis, Radix et Rhizoma Cynanchi Atrati. }\end{array}$ & Curing cold due to exogenous wind-heat in children \\
\hline Dalitong Keli & $\begin{array}{l}\text { Radix Bupleuri, Fructus Aurantii, Radix Aucklandiae, } \\
\text { Pericarpium Citri Reticulatae, Pinelliae Rhizoma } \\
\text { Praeparatum Cum Alumine, Herba Taraxaci, Crataegi } \\
\text { fructus, Semen Arecae, Paederia scandens, Radix } \\
\text { Codonopsis, Rhizoma Corydalis, Massa Medicata } \\
\text { Fermentata. }\end{array}$ & $\begin{array}{l}\text { Curing epigastric fullness, belching, dry mouth, and } \\
\text { mouth pain }\end{array}$ \\
\hline Bubai Keli & $\begin{array}{l}\text { Fructus Psoraleae, Dolichos lablab L., Folium Epimedii, } \\
\text { Radix Bupleuri, Radix et Rhizoma Salviae } \\
\text { miltiorrhizae, Vigna umbellata Ohwi et Ohashi, Radix } \\
\text { Sophorae Flavescentis, Glycine max (L.) Merr. }\end{array}$ & Nourishing the spleen and warming the kidneys \\
\hline Ganmao Qingre Keli & $\begin{array}{l}\text { Schizonepetae Spica, Radix Bupleuri, Herba menthae } \\
\text { haplocalycis, Radix Saposhnikovia, Perillae Folium, } \\
\text { Radix Puerariae lobatae, Radix Platycodonis, Semen } \\
\text { Armeniacae amarum, Radix Angelicae dahuricae, } \\
\text { Corydalis bungeana Herba. }\end{array}$ & $\begin{array}{l}\text { Curing cold, cough, fever, headache, rhinorrhea, and } \\
\text { pharyngoxerosis }\end{array}$ \\
\hline Qizhi Weitong tablet & $\begin{array}{l}\text { Radix Bupleuri, Rhizoma Corydalis, Rhizoma Cyperi, } \\
\text { Fructus Aurantii, Radix Paeoniae Alba, Radix } \\
\text { Glycyrrhizae. }\end{array}$ & $\begin{array}{l}\text { Curing stagnation of liver qi, abdominal distention, and } \\
\text { epigastric pain }\end{array}$ \\
\hline Lidan tablet & $\begin{array}{l}\text { Rheum palmatum, Flos Lonicerae. Japonicae, Herba } \\
\text { Lysimachiae, Radix Aucklandiae, Rhizoma } \\
\text { Anemarrhenae, Folium isatidis, Radix Bupleuri, Radix } \\
\text { Paeoniae Alba, Radix Scutellariae, Natrii Sulfas, Herba } \\
\text { Artemisiae Scopariae. }\end{array}$ & $\begin{array}{l}\text { Curing hypochondriac pain, constipation, oliguria with } \\
\text { reddish urine, headache, and vomiting }\end{array}$ \\
\hline Ruhe Sanjie tablet & $\begin{array}{l}\text { Radix Bupleuri, Radix Angelicae sinensis, Radix } \\
\text { Astragali, Radix Curcumae, Tulipa edulis, Radix } \\
\text { Rhapontici, Ecklonia kurome Okam, Sargassum, } \\
\text { Folium Epimedii, Herba Pyrolae. }\end{array}$ & $\begin{array}{l}\text { Curing lump in breast, and mammary gland } \\
\text { hyperplasia }\end{array}$ \\
\hline Jianwei Yuyang tablet & $\begin{array}{l}\text { Radix Bupleuri, Radix Paeoniae Alba, Radix } \\
\text { Codonopsis, Rhizoma Corydalis, Bletilla striata } \\
\text { (Thunb.) Reiehb. f., Indigo Naturalis, Concha } \\
\text { Margaritifera Usta. }\end{array}$ & $\begin{array}{l}\text { Curing dysphoria, distention and loose stools, and } \\
\text { peptic ulcer }\end{array}$ \\
\hline Longdan Xiegan pill & $\begin{array}{l}\text { Radix et Rhizoma Gentianae, Radix Bupleuri, Radix } \\
\text { Scutellariae, Fructus Gardeniae, Rhizoma alismatis, } \\
\text { Caulis Akebiae, Semen Plantaginis, Radix Angelicae } \\
\text { sinensis, Radix Rehmanniae, Radix Glycyrrhizae. }\end{array}$ & $\begin{array}{l}\text { Curing hepatochlic hygropyrexia, dizziness, deafness, } \\
\text { tinnitus, and mouth-bitterness }\end{array}$ \\
\hline Qingwen Jiedu pill & $\begin{array}{l}\text { Radix Bupleuri, Folium isatidis, Fructus Forsythiae, } \\
\text { Radix Scrophulariae, Radix Trichosanthis, Radix } \\
\text { Platycodonis, Fructus Arctii, Radix Saposhnikovia, } \\
\text { Radix Puerariae lobatae, Radix Scutellariae, Radix } \\
\text { Angelicae dahuricae, Rhizoma Chuanxiong, and others. }\end{array}$ & Curing headache, throat-drying, and mumps \\
\hline Shugan Hewei pill & $\begin{array}{l}\text { Rhizoma Cyperi, Radix Paeoniae Alba, Fructus citri } \\
\text { Sarcodactylis, Radix Aucklandiae, Radix Curcumae, } \\
\text { Rhizoma Atractylodis Macrocephalae, Pericarpium } \\
\text { Citri Reticulatae, Radix Bupleuri, Herba Pogostemonis, } \\
\text { Radix Glycyrrhizae, Semen Raphani, and others. }\end{array}$ & $\begin{array}{l}\text { Curing disharmony between liver and stomach, } \\
\text { epigastric pain, inappetence, and vomiting }\end{array}$ \\
\hline Huayu Quban capsule & $\begin{array}{l}\text { Radix Bupleuri, Radix Scutellariae, Radix Angelicae } \\
\text { sinensis, Herba menthae haplocalycis, Flos Carthami, } \\
\text { Radix Paeoniae Rubra }\end{array}$ & Curing chloasma and acne \\
\hline
\end{tabular}


TABLE 1: Continued.

\begin{tabular}{lll}
\hline Preparation name & Compositions & Traditional uses \\
\hline \multirow{2}{*}{ Ruzengning capsule } & Radix Bupleuri, Folium Artemisiae Argyi, Folium & \\
& $\begin{array}{l}\text { Epimedii, Fructus Toosendan, Radix Asparagi, } \\
\text { Rhizoma bolbostemmatis. }\end{array}$ & Curing lump in breast and mammary gland hyperplasia \\
& $\begin{array}{l}\text { Radix Bupleuri, Radix Angelicae sinensis, Radix } \\
\text { Paeoniae Alba, Atractylodis Macrocephalae Rhizoma, }\end{array}$ & \\
Mangan Jieyu capsule & $\begin{array}{l}\text { Poria, Radix Glycyrrhizae, Herba menthae haplocalycis, } \\
\text { Radix et Rhizoma Salviae miltiorrhizae, Fructus }\end{array}$ & Curing chest congestion, inappetence, abdominal \\
& $\begin{array}{l}\text { Toosendan, Fructus citri, Rhizoma Corydalis, and } \\
\text { others. }\end{array}$ & \\
& $\begin{array}{l}\text { Radix Bupleuri, Radix Scutellariae, Herba menthae } \\
\text { haplocalycis, Radix Angelicae dahuricae, Flos }\end{array}$ & \\
Biyuanshu capsule & $\begin{array}{l}\text { Magnoliae, Fructus Xanthii, Fructus Gardeniae, Radix } \\
\text { et Rhizoma Asari, Rhizoma Chuanxiong, Radix }\end{array}$ & Curing rhinitis and nasosinusitis \\
& Astragali, Radix Platycodonis, Poria, Caulis Akebiae. & \\
\hline
\end{tabular}
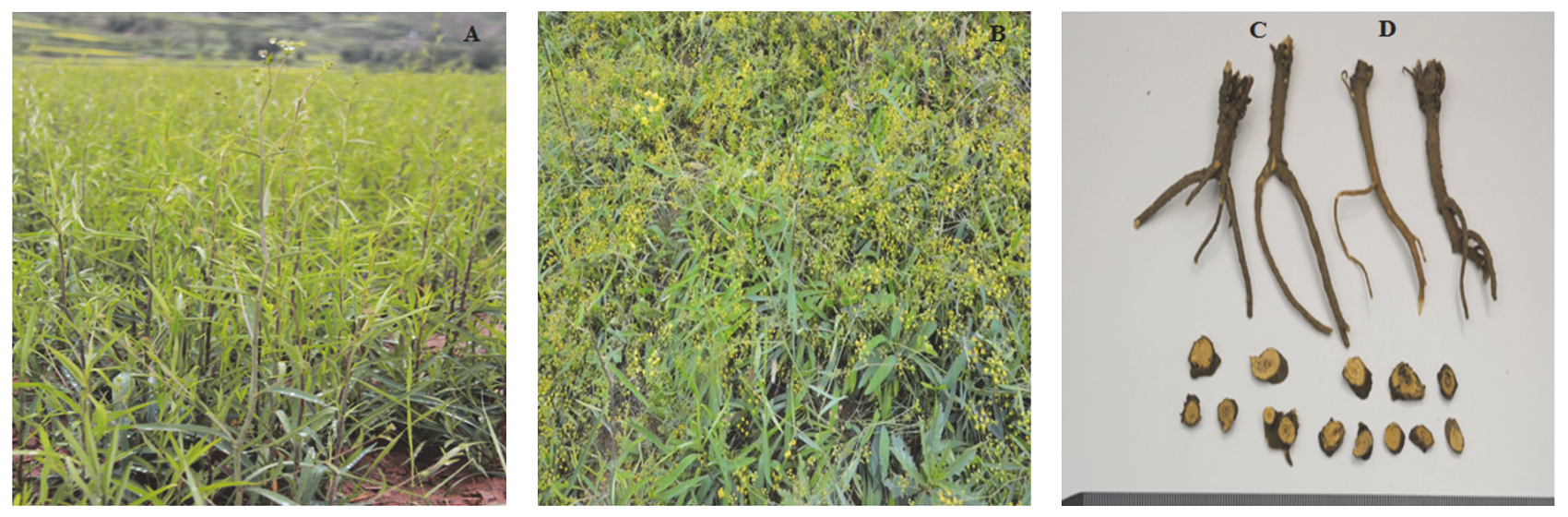

FIgURE 1: The whole plant of Bupleurum chinense DC. (A); the whole plant of Bupleurum scorzonerifolium Willd. (B); the roots of Bupleurum chinense DC (C); the roots of Bupleurum scorzonerifolium Willd. (D).

bioactive compounds owing to their antifungal and antiinflammatory activities [37, 38]. In one study, the essential oils in Radix Bupleuri were extracted by steam distillation and solvent extraction and then analyzed by GC/MS; 78 peaks were identified. Among these peaks, the major volatile compounds were 3-methylbutanal (7.24\%), pentanal (5.74\%), hexanal $(20.11 \%)$, furan-2-carbaldehyde (25.23\%), and heptanal (12.07\%) [39]. However, in another study, the results showed that E-2-heptanal, furan, 2-pentyl, and E-2-nonenal were some of the main compounds of the oil [40].

4.2. Triterpenoid Saponins. Triterpenoid saponins are the main active components of Radix Bupleuri, which exhibit a broad spectrum of biological and pharmacological effects, including analgesic, immunomodulatory, hepatoprotective, immunomodulatory, anti-inflammatory, antitumor, and antiviral activities [3, 41-43]. Currently, approximately 35 saponins have been isolated from Radix Bupleuri (Figure 2) [44-54]. Among them, saikosaponins a, c, and $d$ are the major bioactive constituents found in Radix Bupleuri; however a variety of minor saikosaponins have also been isolated [16]. The cytotoxic and antiproliferative effects of saikosaponins a and $\mathrm{d}$ have been attracting much interest in recent years [55]. Additionally, more information about the intimate relationship between the structural characterization of saikosaponins and their cytotoxic evaluations is very necessary.

4.3. Polyacetylenes. Four polyacetylene compounds from Radix Bupleuri have been identified, including (2Z,8Z,10E)pentadecatriene-4,6-diyne-1-ol (36), (2Z,8E,10E)-pentadecatriene-4,6-diyne-1-ol (37), (2Z,8Z,10E)-heptadecatriene4,6-diyne-1-ol (38), and bupleurynol (39) (Figure 3) [56, 57].

4.4. Flavonoids. So far, twelve flavonoids have been isolated and identified from Radix Bupleuri, including quercetin (40), isorhamnetin (41), isorhamnetin-3-O-glucoside (42), puerarin (43), rutin (44), narcissin (45), eugenin (46), saikochrome A (47), saikochromic acid (48), 7, '4' -dihydroxyisoflavone-7-O- $\beta$-D-glucoside (49), saikochromoside A (50), and saikoisoflavonoside A (51) (Figure 4) [58-63]. 
TABLE 2: Chemical compounds isolated from Radix Bupleuri.

\begin{tabular}{|c|c|c|c|}
\hline Classification & Number & Chemical component & Reference \\
\hline \multirow{35}{*}{ Saponins } & 1 & Saikosaponin a & {$[44]$} \\
\hline & 2 & Saikosaponin c & {$[44]$} \\
\hline & 3 & Saikosaponin d & {$[44]$} \\
\hline & 4 & Saikosaponin e & {$[45]$} \\
\hline & 5 & Prosaikogenin $\mathrm{G}$ & {$[46]$} \\
\hline & 6 & Prosaikogenin F & {$[46]$} \\
\hline & 7 & $2^{\prime \prime}$-O-Acetylsaikosaponin a & {$[47]$} \\
\hline & 8 & $3^{\prime \prime}$-O-Acetylsaikosaponin a & {$[48]$} \\
\hline & 9 & $6^{\prime \prime}-\mathrm{O}-$ Acetylsaikosaponin a & {$[49]$} \\
\hline & 10 & 23-O-Acetylsaikosaponin a & {$[50]$} \\
\hline & 11 & $6^{\prime \prime}-\mathrm{O}$-Acetylsaikosaponin d & {$[51]$} \\
\hline & 12 & $\begin{array}{l}\text { 23-Hydroxy-13 } \beta, 28 \beta \text {-epoxy-olean-11-ene-16-one } \\
\text { 3-O- } \beta \text {-D-glucopyranosyl- }(1 \rightarrow 3) \text { - } \beta \text {-D-fucopyranoside }\end{array}$ & {$[52]$} \\
\hline & 13 & $\begin{array}{l}3 \beta, 16 \beta \text {-Dihydroxy-23-O-acetyl- } 13 \beta, 28 \beta \text {-epoxy-olean-11-ene } \\
3-O-\beta \text {-D-fucopyranoside }\end{array}$ & {$[47]$} \\
\hline & 14 & Bupleuroside I & {$[45]$} \\
\hline & 15 & Saikosaponin $\mathrm{b}_{1}$ & {$[45,49]$} \\
\hline & 16 & Saikosaponin $\mathrm{b}_{2}$ & {$[45,49]$} \\
\hline & 17 & $6^{\prime \prime}$-O-Acetyl-saikosaponin $b_{2}$ & {$[51]$} \\
\hline & 18 & Saikosaponin $\mathrm{h}$ & {$[47,53]$} \\
\hline & 19 & Prosaikogenin D & {$[54]$} \\
\hline & 20 & Prosaikogenin A & {$[47]$} \\
\hline & 21 & $\begin{array}{c}\text { 3 } \beta, 23,28 \text {-Trihydroxy-11, } 13 \text { (18)-diene-16-one } \\
\text { 3-O- } \beta \text {-D-glucopyranosyl-(1 } \rightarrow \\
\text { 3)- } \beta \text {-D-fucopyranoside }\end{array}$ & {$[47]$} \\
\hline & 22 & Bupleuroside V & {$[45]$} \\
\hline & 23 & Bupleuroside X & {$[45]$} \\
\hline & 24 & Bupleuroside XII & {$[45]$} \\
\hline & 25 & Saikosaponin v-1 & {$[51]$} \\
\hline & 26 & Saikosaponin $\mathrm{b}_{3}$ & {$[44,53]$} \\
\hline & 27 & Saikosaponin $\mathrm{b}_{4}$ & {$[44,53]$} \\
\hline & 28 & Saikosaponin $\mathrm{f}$ & {$[45]$} \\
\hline & 29 & $\begin{array}{l}3 \beta, 16 \beta, 23,28 \text {-Tetrahydroxy-11 } \alpha \text {-methoxy-olean-12-ene } \\
\text { 3-O- } \beta \text {-D-fucopyranoside }\end{array}$ & {$[47]$} \\
\hline & 30 & $\begin{array}{l}3 \beta, 16 \beta, 28 \text {-Trihydroxyl-11 } \alpha \text {-methoxy-olean-12-ene-O- } \beta \text {-D- } \\
\text { fucopyranoside }\end{array}$ & {$[47]$} \\
\hline & 31 & Bupleuroside VII & {$[45]$} \\
\hline & 32 & Saikosaponin $g$ & {$[53]$} \\
\hline & 33 & Saikosaponin i & {$[53]$} \\
\hline & 34 & Bupleuroside VIII & {$[45]$} \\
\hline & 35 & Bupleuroside XI & [45] \\
\hline \multirow{4}{*}{ Polyacetylenes } & 36 & $(2 Z, 8 Z, 10 E)$-pentadecatriene-4,6-diyne-1-ol & {$[56]$} \\
\hline & 37 & $(2 \mathrm{Z}, 8 \mathrm{E}, 10 \mathrm{E})$-pentadecatriene-4,6-diyne-1-ol & {$[56,57]$} \\
\hline & 38 & (2Z,8Z,10E)-heptadecatriene-4,6-diyne-1-ol & {$[56]$} \\
\hline & 39 & Bupleurynol & {$[56,57]$} \\
\hline
\end{tabular}


TABLE 2: Continued.

\begin{tabular}{|c|c|c|c|}
\hline Classification & Number & Chemical component & Reference \\
\hline \multirow{12}{*}{ Flavonoids } & 40 & Quercetin & {$[60]$} \\
\hline & 41 & Isorhamnetin & {$[60]$} \\
\hline & 42 & Isorhamnetin-3-O-glucoside & {$[60]$} \\
\hline & 43 & Puerarin & {$[60]$} \\
\hline & 44 & Rutin & {$[60]$} \\
\hline & 45 & Narcissin & {$[59]$} \\
\hline & 46 & Eugenin & {$[62]$} \\
\hline & 47 & Saikochrome A & {$[62,63]$} \\
\hline & 48 & Saikochromic acid & {$[60]$} \\
\hline & 49 & 7,4'-Dihydroxy-isoflavone-7-O- $\beta$-D-glucoside & {$[60]$} \\
\hline & 50 & Saikochromoside A & {$[59]$} \\
\hline & 51 & Saikoisoflavonoside A & {$[61]$} \\
\hline \multirow{8}{*}{ Lignans } & 52 & Nortrachelogenin & {$[63]$} \\
\hline & 53 & Nemerosin & {$[62]$} \\
\hline & 54 & Kaerophyllin & {$[62]$} \\
\hline & 55 & Isochaihulactone & {$[62]$} \\
\hline & 56 & Isokaerophyllin & {$[62]$} \\
\hline & 57 & $(-)$-yatein & {$[62]$} \\
\hline & 58 & Chinensinaphthol & {$[62]$} \\
\hline & 59 & Chaihunaphthone & {$[62]$} \\
\hline \multirow{12}{*}{ Fatty acids } & 60 & Fumaric acid & {$[64]$} \\
\hline & 61 & Butanedioic acid & {$[64]$} \\
\hline & 62 & Pentadecanoic acid & {$[65]$} \\
\hline & 63 & Palmitoleic acid & {$[65]$} \\
\hline & 64 & Palmitic acid & {$[65]$} \\
\hline & 65 & Oleic acid & {$[65]$} \\
\hline & 66 & Stearic acid & {$[65]$} \\
\hline & 67 & 11-Hexadecenoic acid & {$[65]$} \\
\hline & 68 & 13-Octadecenoic acid & {$[65]$} \\
\hline & 69 & Linoleic acid & {$[65]$} \\
\hline & 70 & Tetracosanoic acid & {$[64]$} \\
\hline & 71 & 9S,12S,13S-Trihydroxy-10E-octadecenoic acid & {$[63]$} \\
\hline \multirow{3}{*}{ Sterols } & 72 & $\alpha$-Spinasterol & {$[64]$} \\
\hline & 73 & $24 \xi$-Methylcholesta-7, 22E-diene- $3 \beta, 5 \alpha, 6 \beta$-triol & {$[63]$} \\
\hline & 74 & $24 \xi$-Ethylcholest-22E-end-3 $\beta, 5 \alpha, 6 \beta$-Triol & [63] \\
\hline
\end{tabular}

4.5. Ligans. Lignans existing in numerous plants were detected in the roots of Bupleurum scorzonerifolium Willd. These lignans included nortrachelogenin (52), nemerosin (53), kaerophyllin (54), isochaihulactone (55), isokaerophyllin (56), (-)-yatein (57), chinensinaphthol (58), and chaihunaphthone (59) (Figure 5) [62, 63].

4.6. Other Compounds. There are also other components in Radix Bupleuri, including 12 fatty acids: fumaric acid (60), butanedioic acid (61), pentadecanoic acid (62), palmitoleic acid (63), palmitic acid (64), oleic acid (65), stearic acid (66), 11-hexadecenoic acid (67), 13-octadecenoic acid (68), linoleic acid (69), tetracosanoic acid (70), and 9S,12S,13Strihydroxy-10E-octadecenoic acid (71). Three sterols compounds, namely, $\alpha$-spinasterol (72), $24 \xi$-methylcholesta7, 22E-diene- $3 \beta, 5 \alpha, 6 \beta$-triol (73), and $24 \xi$-ethylcholest-22Eend- $3 \beta, 5 \alpha, 6 \beta$-triol (74) were also isolated and identified from this plant (Figure 6) [63-65].

\section{Pharmacological Effects}

Radix Bupleuri exerts a great variety of pharmacological activities due to its complexbioactive compounds. An overview of the pharmacological studies on Radix Bupleuriis presented in detail in the following sections. 


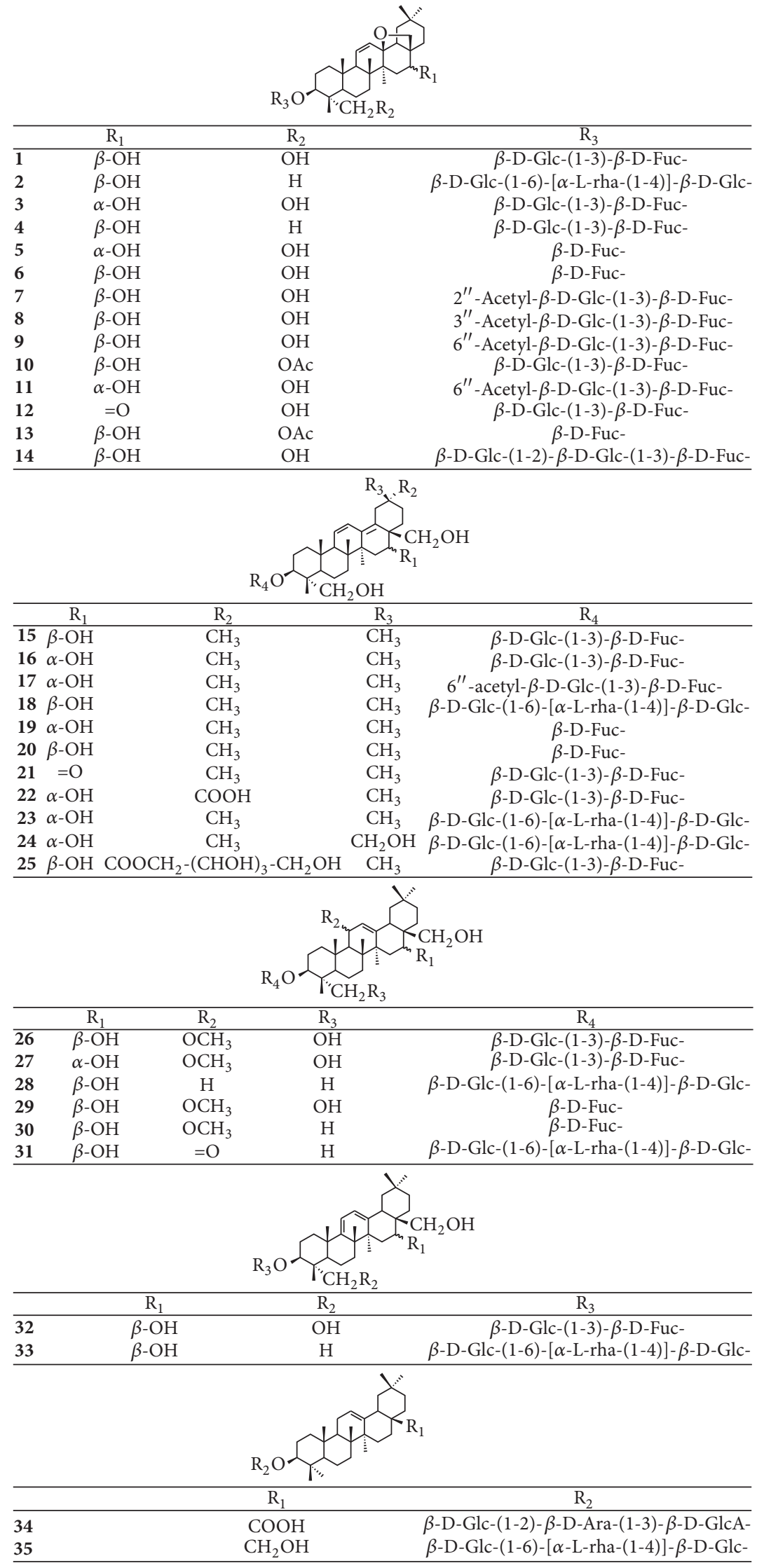

FIGURE 2: Chemical structures of triterpenoid saponins. 


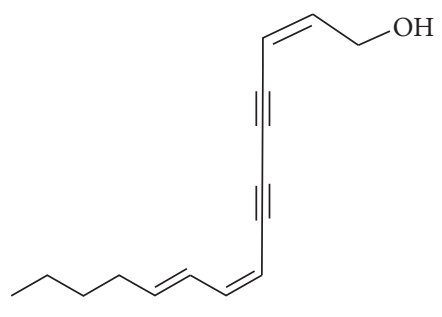

36

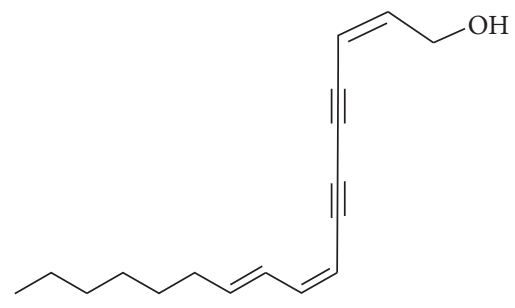

38

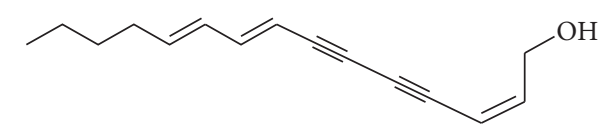

37

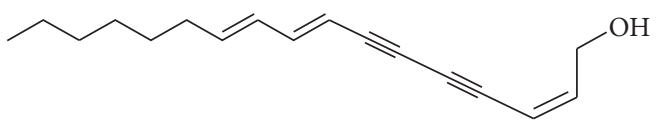

39

FIGURE 3: Chemical structures of polyacetylenes.

5.1. Anti-inflammatory Effects. Radix Bupleuri has been widely used for the treatment of several types of chronic inflammatory diseases. The crude polysaccharides $(80 \mathrm{mg} / \mathrm{kg})$ isolated from the roots of Bupleurum chinense DC. significantly attenuated lung injury by inhibiting the level of myeloperoxidase (MPO), tumor necrosis factor- $\alpha$ (TNF- $\alpha$ ), and serum nitric oxide (NO) [66]. Chun et al. reported that saikosaponins from Radix Bupleuri exhibited anti-inflammatory activity on inflammatory processes including inhibition of inflammatory exudation, capillary permeability, inflammatory mediators release, migration of white cells, connective tissue hyperplasia, and a variety of allergic inflammation [67]. Ma et al. was the first to show that saikosaponins exerted anti-inflammatory activity on paw edema mainly via regulating the nicotinate and nicotinamide metabolism and arachidonic acid metabolism [5]. Zhu et al. found that saikosaponin a (SSa) exhibited an inhibitory effect on proinflammatory cytokines in LPS-stimulated macrophages. The mechanism of these actions involved the regulation of MAPK and NF- $\kappa$ B signals pathways [68]. In another study, SSa dose-dependently inhibited the production of ROS, TNF- $\alpha$, IL-8, COX-2, and iNOS in LPS-stimulated human umbilical endothelial cells (HUVECs) by upregulating of the LXR $\alpha$-ABCA1 signaling pathway [69]. Moreover, Lee et al. showed that saikosaponin c (SSc) was also shown to inhibited LPS-induced apoptosis in HUVECs via inhibition of caspase- 3 activation and caspase3-mediated-FAK degradation [70]. Zhao et al. showed that SSa also suppressed TNF- $\alpha$ and IL- 6 concentrations in the intestines of septic rats through the inhibition of the nucleotide-binding oligomerization domain 2 (NOD2)/NF$\kappa \mathrm{B}$ signaling pathway [71]. Saikosaponin $\mathrm{d}$ (SSd) has been reported to inhibit $\mathrm{PGE}_{2}$ production and intracellular free $\mathrm{Ca}^{2+}$ concentration $\left(\left[\mathrm{Ca}^{2+}\right] \mathrm{i}\right)$ in a concentration-dependent manner with an $\mathrm{IC}_{50}$ value of $3 \mu \mathrm{m}$ in C6 rat glioma cells [72].
In addition, several studies showed that a wide range of Radix Bupleuri preparations also exhibited antiinflammatory effects in in vitro and in vivo model. Li et al. showed that Saireito and its active components (SSd) could suppress the proliferation of mesangial cells and expansion of the mesangial matrix in the rat glomerulonephritis model [73]. In experimental chronic pancreatitis rats model, "Chai-hu-shu-gan powder" exerted anti-inflammatory and antifibrotic effects by inhibiting the expression of nuclear factor- $\kappa \mathrm{B}(\mathrm{NF}-\kappa \mathrm{B})$ and TNF- $\alpha$ mRNA in the pancreas [74]. Furthermore, it also reduced the abnormally high plasma level of cholecystokinin, improved the gastric movement, and avoided nausea and flatulence [75]. In another experiment, a Chinese herbal formula called "RCM-101" (containing Flos magnoliae, Radix Bupleuri, Radix Glycyrrhizae, Radix Angelicae Sinensis, etc.) inhibited the NO production and iNOS protein expression in LPS-stimulated rat aorta and Raw 264.7 macrophages [76].

5.2. Anticancer Effects. The extracts and compounds of Radix Bupleuri also possessed anticancer/antitumor effect. The acetone extract of Bupleurum scorzonerifolium could inhibit the proliferation of A549 human lung cancer cells in a dose-dependent manner via causing cell cycle arrest in the G2/M phase, increasing microtubule stabilization, suppressing telomerase activity, activating ERK 1/2 and caspase-3/9 in A549 cells [77-79]. Saponins isolated from Radix Bupleuri also exhibited significantly anti-proliferative activity in human non-small cell lung cancer A549 cells through Fas-dependent apoptotic pathway [80]. Su et al. found that the water extracts of Radix Bupleuri could enhance 5-fluorouracil-induced cytotoxicity in HepG2 hepatoma cells through cell arrest at the late G1/early S phase, while protecting normal blood lymphocytes [6]. SSd showed very potent activity against the HepG2 cell line with an $\mathrm{IC}_{50}$ value of $12.5 \mathrm{mg} / \mathrm{ml}$. The mechanism of cytotoxicity was 
<smiles>O=c1c(O)c(-c2ccc(O)c(O)c2)oc2cc(O)cc(O)c12</smiles>

40<smiles>COc1cc(-c2oc3cc(O)cc(O)c3c(=O)c2OC2OC(CO)C(O)C(O)C(O)C2O)ccc1O</smiles>

42

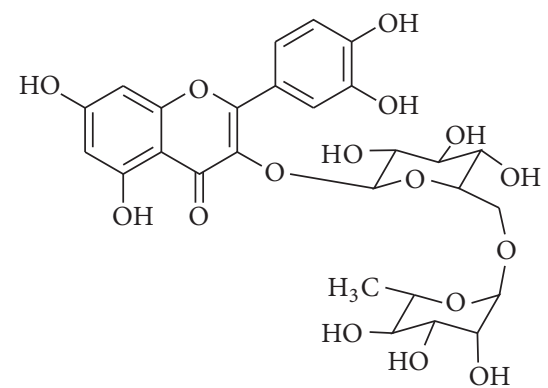

44<smiles>COc1cc(O)c2c(=O)cc(C)oc2c1</smiles>

46<smiles>CC(CO)OC(Oc1ccc2c(=O)c(-c3ccc(O)cc3)coc2c1)C(O)CO</smiles>

49

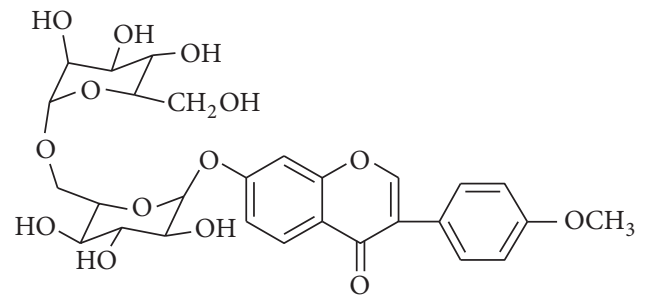

51

FIGURE 4: Chemical structures of flavonoids. attributed to the induction of apoptosis through activation of caspase-3 and caspase-7, which subsequently resulted in poly-ADP-ribose polymerase (PARP) cleavage [81]. The study by $\mathrm{Hou}$ et al. demonstrated that SSd exerted its antitumor effect in human hepatocellular carcinoma cell line SMMC-7721 through the HIF-1 $\alpha /$ COX-2 pathway [82]. Furthermore, SSd was also reported to induce autophagy in HeLa and MCF-7 cancer cells by direct inhibition of 
<smiles>COc1cc(C[C@@H]2COC(=O)C2(O)Cc2ccc(O)c(OC)c2)ccc1O</smiles>

52<smiles>[R]c1cc(/C=C2/C(=O)OC[C@H]2Cc2ccc3c(c2)OCO3)cc(OC)c1OC</smiles><smiles>[R]c1cc(/C=C2\C(=O)OC[C@H]2Cc2ccc3c(c2)OCO3)cc(OC)c1OC</smiles><smiles>COc1cc(C[C@H]2C(=O)OC[C@@H]2Cc2ccc3c(c2)OCO3)cc(OC)c1OC</smiles>

$$
\begin{aligned}
& 53 \mathrm{R}=\mathrm{OCH}_{3} \\
& 54 \mathrm{R}=\mathrm{H}
\end{aligned}
$$<smiles>COc1ccc(-c2c3c(c(O)c4cc5c(cc24)OCO5)COC3=O)cc1OC</smiles>

58
$55 \mathrm{R}=\mathrm{OCH}_{3}$

$56 \mathrm{R}=\mathrm{H}$
57<smiles>COc1cc2cc3c(c(-c4ccc5c(c4)OCO5)c2c(OC)c1OC)COC3=O</smiles>

59

Figure 5: Chemical structures of lignans.

sarcoplasmic/endoplasmic reticulum $\mathrm{Ca}^{2+}$ ATPase (SERCA), leading to the increase of intracellular calcium ion levels and activating the $\mathrm{Ca}^{2+} /$ calmodulin-dependent kinase kinase$\beta$ - (CaMKK $\beta$-) AMP-activated protein kinase- (AMPK-) mammalian target of rapamycin (mTOR) signaling cascade, endoplasmic reticulum (ER) stress, and unfolded protein responses (UPR) [43].

Several Chinese medicine preparations containing Radix Bupleuri also have been traditionally used in the treatment of tumors and cancer. The water extracts of "Long Dan Xie Gan Wan" exerted a significant growth inhibitory effect in HL60 and HT29 cancer cell lines, indicating that this formulation may possess some chemotherapeutic potential [83]. Treatment with "xiao-chai-hu decoction" exhibited a significantly lower incidence of hepatocellular carcinoma and reductions in cancer pain and tumor size. The underlying mechanism of the antitumor activities is based on stimulation of the reticuloendothelial system (RES) and is closely related of TNF production [84-86].

5.3. Antiviral Effects. Wen et al. reported that the acetone extract of Radix Bupleuri possessed a significant antivirus effect on acute respiratory tract infections with H1N1 virus infection and suppressed influenza A virus-induced RANTES secretion in H1N1-infected A549 cells at a concentration of
100 and $200 \mu \mathrm{g} / \mathrm{ml}$, suggesting that Radix Bupleuri might be beneficial for the treatment of chronic inflammatory conditions followed by viral infection [10]. SSc has been reported to show effective anti-HBV activity through inhibiting DNA expression of HBsAg, HBeAg, and HBV [81]. Treatment with "xiao-chai-hu decoction" $(20 \mu \mathrm{g} / \mathrm{ml}, 3$ days; $20 \mu \mathrm{g} / \mathrm{ml}$, 6 days) could inhibit the production of HBV $(P<0.0001)$ and the expression of $\mathrm{HBeAg}$. Moreover, crude saponins of Bupleurum chinense DC. could inhibit the replication of HBV $(P<0.0001)$ [87]. Similarly, in another study, Yin et al. showed that SSd isolated from the $\mathrm{MeOH}$ extract of Bupleurum chinense DC. exhibited significant bioactivity in inhibiting DNA replication of HBV [88]. The antiviral activity of saikosaponins $\left(a, b_{2}, c\right.$, and d) and their mode of actin were examined. The results showed that all saikosaponins exerted antiviral activity on human coronavirus-229E at concentrations of $0.25-25 \mu \mathrm{m}$, and the strongest activity was observed for saikosaponin $\mathrm{b}_{2}$ with an $\mathrm{IC}_{50}$ of $1.7 \mu \mathrm{m}$. This mechanism might involve interference in the early stage of viral replication, such as absorption and penetration of the virus [89].

5.4. Antipyretic Effects. The water extract of Radix Bupleuri was reported to exert its antipyretic effect on dry yeastinduced high fever rats. The mechanism is related to the 
<smiles>O=C(O)/C=C/C(=O)O</smiles>

60<smiles>CCCCCC/C=C/CCCCCCCC(=O)O</smiles>

63<smiles>CCCCCCCCC/C=C/CCCCCCCC(=O)O</smiles>

65<smiles>CCCCCCCCCCCCCCCCCCC(=O)O</smiles>

66<smiles>CCCC/C=C/CCCCCCCCCC(=O)O</smiles>

67<smiles>CCCCC=CCCCCCCCCCCCCC(=O)O</smiles>

68<smiles>CCCCCC=CCCCCCCCCCCC(=O)O</smiles>

69<smiles>CCCCCCCCCCCCCCCCCCCCCCCC(=O)O</smiles>

70<smiles>CCCCCC(O)C(O)C=C[C@@H](O)CCCCCCCC(=O)O</smiles>

71<smiles>CCC(/C=C/[C@@H](C)[C@H]1CCC2C3=CC[C@H]4CC(O)CCC4(C)C3CCC21C)C(C)C</smiles>

72<smiles>CC(C)C(C)/C=C/[C@H](C)C1CCC2C3=C[C@H](O)[C@]4(CO)CCC(O)CC4(C)C3CCC21C</smiles>

73<smiles>CCC(/C=C/[C@H](C)C1CCC2C3CC(O)[C@@]4(CO)CCC(O)CC4(C)C3CCC21C)C(C)C</smiles>

74

FIGURE 6: Chemical structures of other compounds.

adjustment of synthesis and exudation of cyclic adenosine monophosphate (cAMP) and arginine vasopressin (AVP) [90]. A novel in situ gel system for nasal delivery of the essential oil from Radix Bupleuri was prepared. The results suggested that Radix Bupleuri in situ gel can be more effective than the solution in the treatment of fever [91]. A similar study showed that the essential oil extracted from the herb exhibited dose-dependent antipyretic capacity on both fevered rabbits and rats [92].

5.5. Antibacterial Effects. The ethanol extract of Bupleurum chinense DC. exerted a remarkable bacteriostatic effect on Gram-negative microorganism Helicobacter pylori. The bioactive minimum inhibitory concentration (MIC) 
value was $60 \mathrm{Mm}$ [93]. Saikosaponins isolated from Radix Bupleuri have been reported to exhibit antibacterial activity, particularly against Pseudomonas aeruginosa and Listeria monocytogenes. The protective effect was attributed to the immunomodulatory action on macrophages [94]. "Chaihu injection" has also been tested for possible antimicrobial activity in vitro. The results demonstrated that mild inhibition of Staphylococcus aureus was observed but no effects were observed against Staphylococcus albus, Neisseria gonorrhoeae, Diplococcus pneumoniae, haemolytic Streptococcus, or Pseudomonas aeruginosa [95].

5.6. Hepatoprotective Effects. The liver protective effects against $\mathrm{CCl}_{4}$ induced liver injury were investigated after treatment of mice with raw and vinegar-baked Radix Bupleuri ( $5 \mathrm{~g} / \mathrm{kg} /$ day) for 14 days. The results showed that both raw and processed Radix Bupleuri showed liver protective effects against $\mathrm{CCl}_{4}$ induced liver injury, and the vinegar-baked Radix Bupleuri exerted better effects than that of raw Radix Bupleuri [96]. Pretreated with saikosaponins, especially SSa or SSd, showed remarkable inhibition of D-galactosamineinduced hepatic injury through decreasing the activity of glucose-6-phosphatase and NADPH-cytochrome $\mathrm{C}$ reductase and increasing $5^{\prime}$-nucleotidase activity [97]. Similarly, bupleurosides III, VI, IX, and XIII and saikosaponin $\mathrm{b}_{3}$ isolated from Bupleurum scorzonerifolium Willd. were also found to exhibit protective effect on the D-galactosamineinduced cytotoxicity in primary cultured rat hepatocytes [98]. Further studies also demonstrated that the protective effects of saikosaponins isolated from Bupleurum chinense DC. could prevent hepatocyte injury through regulating intracellular calcium levels [99]. In a rat model with $\mathrm{CCl}_{4}$ induced acute hepatic injury, the hepatic enzyme levels (GOT, GPT, and ALP) and the lipid peroxidation in the liver were significantly reduced by the administration of SSd [100]. Additionally, SSd significantly reduced collagen I deposition and alanine aminotransferase level on liver fibrosis rats and decreased the concentration of transforming growth factor $\beta 1$ (TGF- $\beta 1$ ). Moreover, SSd was able to alleviate hepatocyte injury from oxidative stress. The effect of SSd on liver fibrosis may be related to its ability to reduce lipid peroxidation [101].

5.7. Immunomodulatory Effects. Yamakage et al. determined the effects of Radix Bupleuri on spontaneous lymphatic vessel activity. The results indicated that Radix Bupleuri significantly increased the amplitude of spontaneous activity of lymphatic vessels in a concentration-dependent manner, and the mechanisms of this effect seem to be independent of endothelial function [102]. Eugenin (46) and saikochrome A (47) isolated from the $\mathrm{MeOH}$ extracts from Bupleurum scorzonerifolium possessed immunosuppressive effect on human peripheral blood T cells via inhibiting CD28-costimulated activation [62]. SSd (10 mg, intraperitoneally) significantly activated peritoneal macrophages in terms of enhancement of phagocytic activity, increased level of cellular lysosomal enzyme, and suppressed the response of plaque-forming cells to heterologous erythrocytes by stimulating $\mathrm{T}$ and $\mathrm{B}$ cells in a dose-dependent manner [103]. Moreover, SSd modulated lymphocyte activity through suppressing the $\mathrm{T}$ cell response and increasing the $\mathrm{B}$ cell response to different mitogens and the interleukin- (IL-) 2/IL-4 production through a receptor-bypassed pathway $[41,104,105]$. In another experiment, Wong et al. found that SSd was shown to inhibit OKT3/CD28-costimulated human $\mathrm{T}$ cell proliferation and PMA, PMA/ionomycin, and Con A-induced mouse $\mathrm{T}$ cell activation in vitro. The underlying mechanisms involved downregulation of NF-kB signaling by suppression of IKK and Akt activities [106].

5.8. Autophagic Effect. Autophagy is a complex process in cells, which occurs through the formation of doublemembrane vesicles (autophagosomes), which are engulfed by cytoplasmic molecules. Then, the autophagosome fuses with the lysosomes, leading to degradation of long-lived proteins, aggregated proteins, and damaged organelles [107109]. Moreover, autophagy might be triggered by hypoxia, nutritional deprivation, radiation, chemical drugs, and other stimulants [110]. Autophagy contributes to the pathogenesis of diverse diseases, such as neuronal degeneration, inflammatory bowel disease, aging, and cancer $[111,112]$. In the previous study, Law et al. demonstrated that the protective pharmacological effects of Radix Bupleuri might be attributed to its autophagy induction. The autophagic effect of Radix Bupleuri played an important role in relieving liver disease-related symptoms through anti-inflammatory, organ-protective, and aggregate removal functions. Furthermore, the anticancer effects of Radix Bupleuri could be attributed to its autophagy induction. Radix Bupleuri has been found to be an effective treatment against depression by regulating metabolite, hormone, and neurotransmitter levels via autophagy-mediated lipid metabolism [113].

5.9. Other Pharmacological Effects. The effect of the ethanol extract from Radix Bupleuri on cytochrome 450 isoform activities using a six-drug cocktail approach was evaluated; the results demonstrated that Radix Bupleuri had strong induction activity on the CYP2E1, CYP2D6, and CYP3A4, which may lead to potential plant drug-drug interactions [114]. Radix Bupleuri was shown to be the inhibitor of $\beta$ glucuronidase. The inhibition rate of Radix Bupleuri extracts RB1 (high molecular weight polysaccharides), RB2 (ethanol soluble/water insoluble component), RB3 (extracted by nbutanol, soluble in water), and RB4 (low molecular weight water soluble parts) on the activity of $\beta$-glucuronidase was found to be $45.15 \%, 33.94 \%, 24.94 \%$, and $34.54 \%$, respectively [115]. In pentylenetetrazol (PTZ) induced epilepsy rats model, SSa isolated from Radix Bupleuri significantly reduced seizure severity and duration while it markedly elevated seizure latency and downregulated the cytokines expression of $\mathrm{p}$ mTOR, p-70S6K, L-1 $\beta$, and TNF- $\alpha$ through inhibiting mTOR signaling pathway [116]. He et al. demonstrated that SSa obviously reduced lipoprotein uptake to block foam cell formation and the expression of LOX-1 and CD36, boosted cholesterol efflux, and the expression of ABCA1 and PPAR $\gamma$ through inhibiting PI3K/Akt/NF- $\kappa \mathrm{B} / \mathrm{NLRP} 3$ signaling pathway [117]. 
In another experiment, SSc exerted a potent effect on inducing human umbilical vein endothelial cells (HUVECs) viability and growth. Furthermore, SSc also induced endothelial cells migration and capillary tube formation. The underlying mechanisms might be related to the gene expression or activation of matrix metalloproteinase-2 (MMP-2), vascular endothelial growth factor (VEGF), and the p42/p44 mitogenactivated protein kinase (MAPK, ERK) [118]. In addition, SSc was shown to exhibit inhibitory activities against Alzheimer's disease $(A D)$ via suppressing the secretion of $A \beta$ peptides and abnormal tau hyperphosphorylation-mediated microtubule depolymerization. Moreover, SSc suppressed A $\beta$ peptideinduced brain endothelial apoptosis, indicating that Ssc might be a novel therapeutic tool for treating human AD and other neurodegenerative diseases [119]. It was shown by Liu et al. for the first time that four polyacetylenes (36-39) from Radix Bupleuri potently exhibited an antidepressant activity by inhibiting the reuptake of serotonin, norepinephrine, and dopamine. The mechanism might be mediated by increasing the level of monoamines, particularly 5-HT and NE [56]. Zhu et al. suggested that SSa and SSd exhibited the anthelmintic activity against Dactylogyrus spp. infecting goldfish. The effective concentration $\left(\mathrm{EC}_{50}\right)$ values for SSa and SSd were 1.46 and $0.74 \mathrm{mg}^{-1}$, respectively [120].

5.10. Summary of Pharmacological Effects. Radix Bupleuri possesses a wide spectrum of pharmacological effects, including anti-inflammatory effect, anticancer effect, antiviral effect, antipyretic effect, antibacterial effect, hepatoprotective effect, and immunomodulatory effect (Table 3). Based on these pharmacological effects, we can conclude that the extracts and the compounds from this plant can prevent or treat certain diseases, such as cancer, fever, malaria, hepatitis, and AD. However, there is not enough systemic data of these chemical compounds and their pharmacological effects. Thus, in the future, the pharmacological effects and the possible molecular mechanisms of the pharmacological activities of Radix Bupleuri must be urgently explored on our modern understanding of these diseases' pathophysiologies.

\section{Toxicology}

Radix Bupleuri has been used for thousands of years as an important traditional herb in China. However, the toxic effects of Radix Bupleuri in clinical applications have been gradually reported. Several studies have found that the liver is the main organ affected by toxicity, particularly in longterm use. Major symptoms of liver injury induced by Radix Bupleuri included transaminase lifts, hepatitis, and jaundice. However, liver functions can return to normal levels after a specific period [121]. Radix Bupleuri has been reported to exhibit acute hepatitis and acute hepatic necrosis. The mean total daily dose was $18.0 \pm 33.5 \mathrm{~g}$, which was more than the Chinese Pharmacopoeia recommended range of 3 to $10 \mathrm{~g}$ [122]. Moreover, Radix Bupleuri had been implicated in multiple cases of acute hepatitis both as an ingredient alone and within a particular formulation "Xiao-Chai-Hu-Tang" (also known as Syo-Saiko-To in Japanese) [123]. Lee et al. demonstrated that two Chinese herbal products containing Radix Bupleuri might increase their risks of liver injury in HBV-infected patients. However, further mechanistic research on the hepatotoxicity of Radix Bupleuri in the presence of HBV infection is warranted [124]. In addition, the essential oil of Radix Bupleuri induced acute hepatotoxicity with asynchronous state, higher heart rate, and fast breathing [125]. The total saponins isolated from Radix Bupleuri could also cause evidently liver damage in dose-dependent manner manifested as hepatocyte organic lesion and liver function changes, as well as hepatocyte death [126].

\section{Pharmacokinetics}

A selective and sensitive LC-MS/MS method was developed and validated for simultaneous determination of SSa, $b_{2}, c$, and $\mathrm{d}$ in rat plasma afteroral administration of the ethanolwater $(50: 50, \mathrm{v} / \mathrm{v})$ extract of Radix Bupleuri for the first time. The results demonstrated that SSa, c, and d were absorbed rapidly with $T_{\max }$ less than $30 \mathrm{~min}$ [127]. In another pharmacokinetics experiment of rats, Liu et al. was the first to develop an UPLC-PDA-MS method to determine the pharmacokinetics of four polyacetylenes after i.g. administration of $95 \%$ ethanol extract of Radix Bupleuri. The results showed that compounds $\mathbf{3 6}$ and $\mathbf{3 8}$ were not detected in rat serum, whereas compounds $\mathbf{3 7}$ and $\mathbf{3 9}$ exerted a fast distribution phase followed by a relatively slow elimination phase $\left(t_{1 / 2 z}\right.$, 4-7 h) [56].

\section{Future Perspectives and Conclusions}

In traditional Chinese medicine, Radix Bupleuri has long been used regulate the exterior and interior metabolisms, disperse evil heat from superficies, sooth the liver, and promote yang and qi. It has been widely used to treat various diseases in China, Japan, Korea, and other Asian countries for many centuries. A total of 74 compounds including essential oils, triterpenoid saponins, polyacetylenes, flavonoids, lignans, fatty acids, and sterols have been isolated and identified from Radix Bupleuri [39-65]. Pharmacological studies have revealed that Radix Bupleuri possesses a variety of biological effects, including anti-inflammatory, anticancer, antiviral, antipyretic, antibacterial, antiobesity, immunomodulatory, hepatoprotective, neuroprotective, and autophagic effects [66-120]. However, there are some aspects that need to be further investigated.

Radix Bupleuri is an ingredient of many patent medicines or prescriptions. Although modern experiments have confirmed that this drug alone exhibits multiple pharmacological activities, it is important to investigate the molecular mechanisms of Radix Bupleuri combined with other herbs based on traditional uses. Furthermore, the pharmacological effects of only a few of the ingredients, such as saikosaponins, flavonoids, and the essential oils, have been investigated. Some polyacetylenes, lignans, and sterols have not been sufficiently researched in terms of their pharmacological effects. Radix Bupleuri shows both hepatoprotection and 


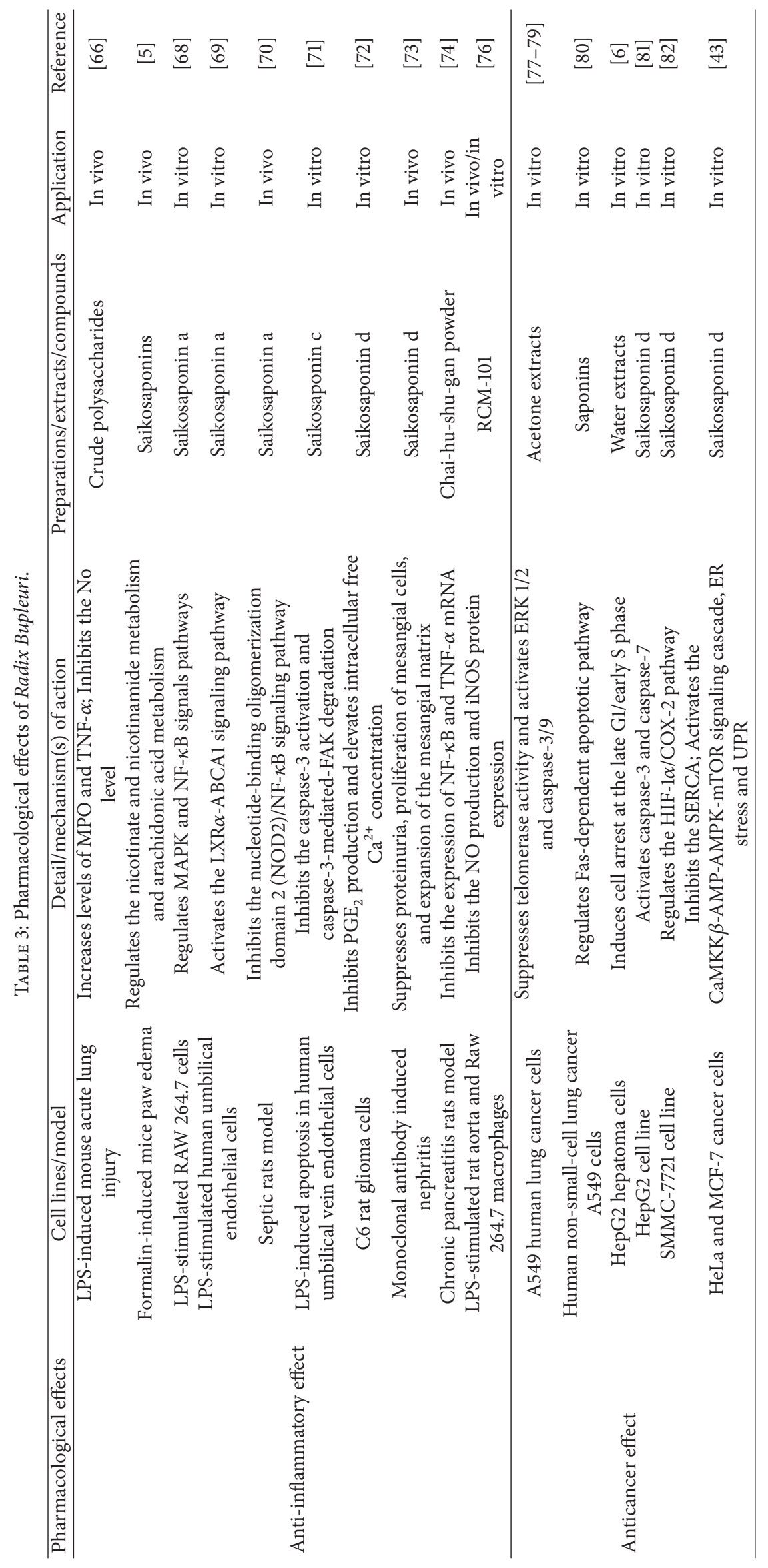




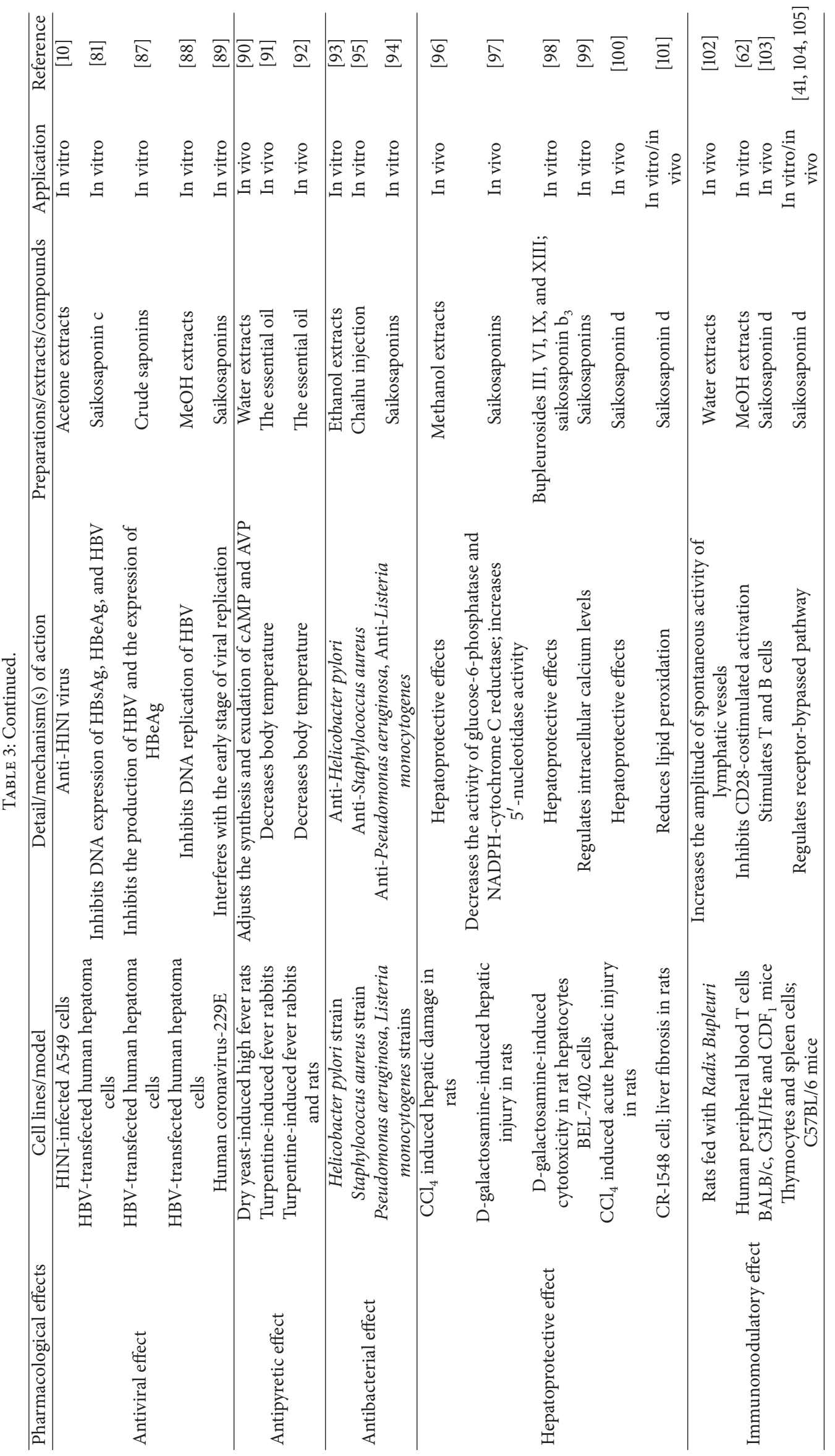




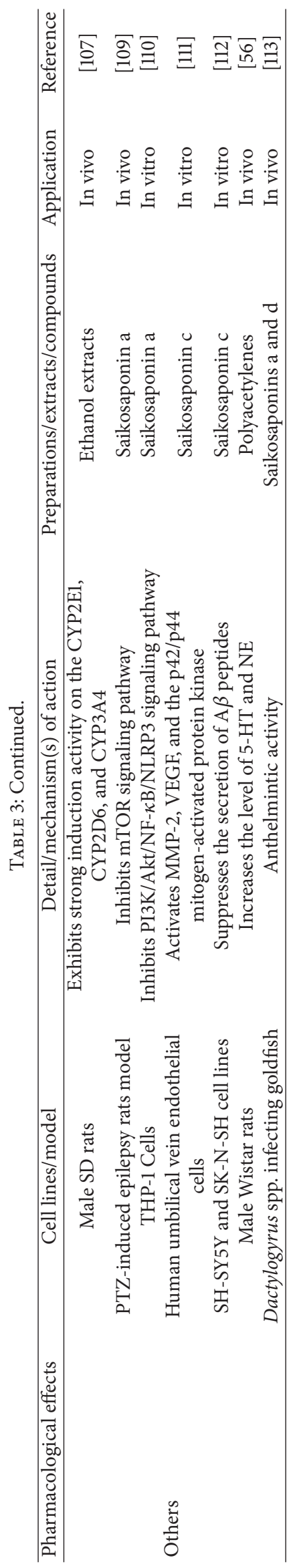


hepatotoxicity, which appears to be contradictory. This phenomenon is similar to that of Polygonum multiflorum Thunb. [128]. Based on the literature, the main reasons are likely the administration dosage and delivery time. High doses and long-term drug delivery are more likely to result in liver toxicity, whereas low doses and short-term drug delivery might result in liver protection. Therefore, this issue needs further study.

In conclusion, this review summarized the traditional uses, botany, phytochemistry, pharmacology, and toxicology of Radix Bupleuri. Moreover, it has provided a new foundation for further research on its mechanism of action and the development of better therapeutic agents employing Radix Bupleuri in the future. It is anticipated that the comprehensive and detailed research on toxicity, pharmacodynamics, pharmacokinetics, and molecular mechanism are necessary to be explored to develop its bioactive compounds as effective drugs.

\section{Conflicts of Interest}

The authors have declared that there are no conflicts of interest regarding the publication of this paper.

\section{Authors' Contributions}

Fude Yang and Xiaoxv Dong contributed equally to this work and share first authorship.

\section{Acknowledgments}

This work was financially supported by the Collaborative Innovation Construction Plan of Beijing University of Chinese Medicine (no. 2013-XTCX-03).

\section{References}

[1] Editorial Committee of Chinese Pharmacopoeia, Chinese Pharmacopoeia, Medical Science and Technology Press, Beijing, China, 2015 edition, 2015.

[2] Y. S. Wang, H. M. Chang, and P. P. H. But, Pharmacology and applications of Chinese, Material Medica World Scientific, Singapore, 1987.

[3] M. L. Ashour and M. Wink, "Genus Bupleurum: a review of its phytochemistry, pharmacology and modes of action," The Journal of Pharmacy and Pharmacology, vol. 63, no. 3, pp. 305321, 2011.

[4] B. P. Bermejo, M. J. A. Martinez, A. M. S. Sen et al., "In vivo and in vitro antiinflammatory activity of saikosaponins," Life Sciences, vol. 63, no. 13, pp. 1147-1156, 1998.

[5] Y. Ma, Y. Bao, S. Wang et al., "Anti-inflammation effects and potential mechanism of saikosaponins by regulating nicotinate and nicotinamide metabolism and arachidonic acid metabolism," Inflammation, vol. 39, no. 4, pp. 1453-1461, 2016.

[6] J. K. Su, Y. J. Lee, B. M. Kim et al., "Effect of Bupleuri Radix Extracts on the Toxicity of 5-Fluorouracil in HepG2 Hepatoma Cells and Normal Human Lymphocytes," Basic \& Clinical Pharmacology \& Toxicology, vol. 103, no. 4, pp. 305-313, 2008.
[7] Y. Motoo and N. Sawabu, "Antitumor effects of saikosaponins, baicalin and baicalein on human hepatoma cell lines," Cancer Letters, vol. 86, no. 1, pp. 91-95, 1994.

[8] M. S. Idris-Usman, "Antinociceptive and antipyretic properties of the pharmaceutical herbal preparation, Radix bupleuri in rats," Journal of Medicinal Plants Research, vol. 4, no. 8, pp. 659663, 2010.

[9] Q. Zhou, S.-S. Wang, G. Yang, W. Zhao, and H.-L. Li, "Development and evaluation of a herbal formulation with antipathogenic activities and probiotics stimulatory effects," Journal of Integrative Agriculture, vol. 15, no. 5, pp. 1103-1111, 2016.

[10] S. Wen, H. F. Xu, and H. Hao, "In vitro anti-influenza A H1N1 effect of extract of Bupleuri Radix," Immunopharmacology and Immunotoxicology, vol. 33, no. 3, pp. 433-437, 2011.

[11] M. Yoshikawa, T. Murakami, K. Hirano, M. Inadzuki, K. Ninomiya, and H. Matsuda, "Scorzonerosides A, B and C, novel triterpene oligoglycosides with hepatoprotective effect from Chinese Bupleuri radix, the roots of Bupleurum scorzonerifolium Willd.," Tetrahedron Letters, vol. 38, no. 42, pp. 73957398, 1997.

[12] Z. Wang, H. Li, H. Xu et al., "Beneficial effect of Bupleurum polysaccharides on autoimmune disease induced by Campylobacter jejuni in BALB/c mice," Journal of Ethnopharmacology, vol. 124, no. 3, pp. 481-487, 2009.

[13] H. Abe, M. Sakaguchi, H. Konishi, T. Tani, and S. Arichi, "The effects of saikosaponins on biological membranes," Planta Medica, vol. 34, no. 6, pp. 160-166, 1978.

[14] S. L. Pan, "Bupleurum species: scientific evaluation and clinical applications," Tayloc and Trancis Group, FLa, USA, 2006.

[15] R.-T. Tian, P.-S. Xie, and H.-P. Liu, "Evaluation of traditional Chinese herbal medicine: Chaihu (Bupleuri Radix) by both high-performance liquid chromatographic and highperformance thin-layer chromatographic fingerprint and chemometric analysis," Journal of Chromatography A, vol. 1216, no. 11, pp. 2150-2155, 2009.

[16] H. Q. Huang, X. Zhang, Z. X. Xu, J. Su, and S. K. Yan, "Fast determination of saikosaponins in Bupleurum by rapid resolution liquid chromatography with evaporative light scattering detection," Journal of Pharmaceutical \& Biomedical Analysis, vol. 49, no. 4, pp. 1048-1055, 2009.

[17] C. Sui, J.-H. Wei, S.-L. Chen, H.-Q. Chen, L. M. Dong, and C.M. Yang, "Construction of a full-length enriched cDNA library and analysis of 3111 ESTs from roots of Bupleurum Chinense DC," Botanical Studies, vol. 51, no. 1, pp. 7-16, 2010.

[18] H. Xie, K.-K. Huo, Z. Chao, and S.-L. Pan, "Identification of crude drugs from Chinese medicinal plants of the genus Bupleurum using ribosomal DNA ITS sequences," Planta Medica, vol. 75, no. 1, pp. 89-93, 2009.

[19] L.-M. Hsu, Y.-S. Huang, S.-H. Tsay, F.-Y. Chang, and S.-D. Lee, "Acute hepatitis induced by Chinese hepatoprotective herb, xiao-chai-hu-tang," Journal of the Chinese Medical Association, vol. 69 , no. 2, pp. 86-88, 2006.

[20] B. E. Van Wyk and M. Wink, Medicinal Plants of the World: An Illustrated Scientific Guide to Important Medicinal Plants and Their Uses, vol. 58, Timber Press, Portland, 1st edition, 2004.

[21] J. Y. Xiong, N. Zang, C. Y. Zhang et al., "Studies on the antidepression effect of Xiaoyao Powder in mic," Pharmacology and Clinics of Chinese Materia Medica, vol. 23, no. 1, pp. 3-5, 2007.

[22] Y. Zhou, Y. Ren, Z. Ma et al., "Identification and quantification of the major volatile constituents in antidepressant active fraction of xiaoyaosan by gas chromatography-mass spectrometry," Journal of Ethnopharmacology, vol. 141, no. 1, pp. 187-192, 2012. 
[23] X. Gao, X. Zheng, Z. Li et al., "Metabonomic study on chronic unpredictable mild stress and intervention effects of Xiaoyaosan in rats using gas chromatography coupled with mass spectrometry," Journal of Ethnopharmacology, vol. 137, no. 1, pp. 690-699, 2011.

[24] Editorial Board of Flora of China, Flora of China, Science Publishing House, Beijing, China, 1998.

[25] Y. Z. Wang and Y. Y. Zhang, "Determination of species of medical Bupleunum," Chinese Pharmaceutical Journal, no. 1, pp. 3-8, 1994.

[26] S. L. Pan, Q. S. Shun, Q. M. Bo, and X. S. Bao, The coloured atlas of the medicinal plants from genus Bupleurum in China, Shanghai Scientific and Technical Literature Press, Shangha, 2002.

[27] M. H. Yen, C. C. Lin, C. H. Chuang, and S. Y. Liu, "Evaluation of root quality of Bupleurum species by TLC scanner and the liver protective effects of "xiao-chai-hu-tang," Journal of Ethnopharmacology, vol. 34, no. 2-3, pp. 155-165, 1991.

[28] X.-Q. Li, Q.-T. Gao, X.-H. Chen, and K.-S. Bi, "High performance liquid chromatographic assay of saikosaponins from Radix Bupleuri in China," Biological and Pharmaceutical Bulletin, vol. 28, no. 9, pp. 1736-1742, 2005.

[29] Q. Zhou, J. P. Hao, and K. Q. Gao, "Analysis on Saikosaponin of Sixteen Bupleurum chinense from Shanxi," Natural Product Research \& Development, vol. 24, no. 5, pp. 644-647, 2012.

[30] Y.-H. Tang, Y.-Y. Zhang, H.-Y. Zhu, and C.-G. Huang, "A highperformance liquid chromatographic method for saikosaponin a quantification in rat plasma," Biomedical Chromatography, vol. 21, no. 5, pp. 458-462, 2007.

[31] H. Zhang, Y. Zhao, H. Liang, L. Huang, Q. Zhang, and X. Zhi, "Simultaneous HPLC-ELSD determination of saikosaponins a, c, d, f in Radix Bupleuri," Chinese Journal of Pharmaceutical Analysis, vol. 27, no. 8, pp. 1150-1153, 2007.

[32] R. Lucena, S. Cárdenas, and M. Valcárcel, "Evaporative light scattering detection: Trends in its analytical uses," Analytical and Bioanalytical Chemistry, vol. 388, no. 8, pp. 1663-1672, 2007.

[33] Y. Bao, C. Li, H. Shen, and F. Nan, "Determination of saikosaponin derivatives in Radix bupleuri and in pharmaceuticals of the Chinese multiherb remedy Xiaochaihu-tang using liquid chromatographic tandem mass spectrometry," Analytical Chemistry, vol. 76, no. 14, pp. 4208-4216, 2004.

[34] B.-C. Liau, S.-S. Hsiao, M.-R. Lee, T.-T. Jong, and S.-T. Chiang, "Quality control of Chinese medicinal preparations. LC/ESI(+)/MS/MS analyses of saikosaponins-a and -c as markers of Bupleuri radix samples," Journal of Pharmaceutical and Biomedical Analysis, vol. 43, no. 3, pp. 1174-1178, 2007.

[35] Y. Chen, J. Wang, L. Yuan, L. Zhou, X. Jia, and X. Tan, "Interaction of the main components from the traditional chinese drug pair chaihu-shaoyao based on rat intestinal absorption," Molecules, vol. 16, no. 11, pp. 9600-9610, 2011.

[36] X. Lin, L. Xue, H. Zhang, and C. Zhu, "Determination of saikosaponins a, c, and d in Bupleurum Chinese DC from different areas by capillary zone electrophoresis," Analytical and Bioanalytical Chemistry, vol. 382, no. 7, pp. 1610-1615, 2005.

[37] A. M. Fernandez-Ocana, M. V. Gomez-Rodriguez, and A. Velasco-Negueruela, "In vivo antifungal activity of the essential oil of Bupleurum gibraltarium against Plasmopara halstedii in sunflower," Journal of Agricultural \& Food Chemistry, vol. 52, no. 21, pp. 6414-6417, 2004.

[38] M. A. Ocete, S. Risco, A. Zarzuelo, and J. Jimenez, "Pharmacological activity of the essential oil of Bupleurum gibraltaricum:
Anti-inflammatory activity and effects on isolated rat uteri," Journal of Ethnopharmacology, vol. 25, no. 3, pp. 305-313, 1989.

[39] S. H. Liu, S. S. Lu, Y. L. Su, and Y. Guo, "Analysis of volatile compounds in Radix bupleuri injection by GC-MS-MS," Chromatographia, vol. 74, no. 5-6, pp. 497-502, 2011.

[40] X. Li, Y. Jia, A. Song, X. Chen, and K. Bi, "Analysis of the essential oil from Radix Bupleuri using capillary gas chromatography," Yakugaku Zasshi, vol. 125, no. 10, pp. 815-819, 2005.

[41] Y. Ushio and H. Abe, "The effects of saikosaponin on macrophage functions and lymphocyte proliferation," Planta Medica, vol. 57, no. 6, pp. 511-514, 1991.

[42] Y. Ushio and H. Abe, "Inactivation of measles virus and herpes simplex virus by Saikosaponin d," Planta Medica, vol. 58, no. 2, pp. 171-173, 1992.

[43] V. K. Wong, T. Li, B. Y. Law et al., "Saikosaponin-d, a novel SERCA inhibitor, induces autophagic cell death in apoptosisdefective cells," Cell Death \& Disease, vol. 4, no. 7, Article no. e720, 2012.

[44] H. Otsuka, "Separation and determination of saponins of bupleuri radix by droplet counter current chromatography (DCC)," Planta Medica, vol. 33, no. 2, pp. 152-159, 1978.

[45] H. Matsuda, T. Murakami, K. Ninomiya, M. Inadzuki, and M. Yoshikawa, "New hepatoprotective saponins, bupleurosides III, VI, IX, and XIII, from Chinese Bupleuri Radix: Structurerequirements for the cytoprotective activity in primary cultured rat hepatocytes," Bioorganic and Medicinal Chemistry Letters, vol. 7, no. 17, pp. 2193-2198, 1997.

[46] J.-K. Ding, H. Fujino, R. Kasai et al., "Chemical evaluation of Bupleurum species collected in Yunnan, China," Chemical and Pharmaceutical Bulletin, vol. 34, no. 3, pp. 1158-1167, 1986.

[47] D. Q. Li, J. Wu, L. Y. Liu et al., "Cytotoxic triterpenoid glycosides (saikosaponins) from the roots of Bupleurum chinense," Bioorganic \& Medicinal Chemistry Letters, vol. 25, no. 18, pp. 38873892, 2015.

[48] H. Seto, N. Otake, S. Q. Luo, F. G. Qian, and G. Y. Xu, "Studies on chemical constituents of Bupleurum genus. Part II. Isolation of triterpenoid glycosides (saikosaponins) from Bupleurum kunmingense and their chemical structures," Agricultural \& Biological Chemistry, vol. 50, no. 4, pp. 943-948, 1986.

[49] Y.-Y. Yang, Y.-Z. Tang, C.-L. Fan, H.-T. Luo, P.-R. Guo, and J.-X. Chen, "Identification and determination of the saikosaponins in Radix bupleuri by accelerated solvent extraction combined with rapid-resolution LC-MS," Journal of Separation Science, vol. 33, no. 13, pp. 1933-1945, 2010.

[50] H. Ishii, M. Nakamura, S. Seo, K. Tori, T. Tozyo, and Y. Yoshimura, "Isolation, characterization, and nuclear magnetic resonance spectra of new saponins from the roots of Bupleurum falcatum L.," Chemical and Pharmaceutical Bulletin, vol. 28, no. 8, pp. 2367-2373, 1980.

[51] Q.-X. Liu, H. Liang, Y.-Y. Zhao, B. Wang, W.-X. Yang, and Y. Yu, "Saikosaponin v-1 from roots of Bupleurum chinense DC.", Journal of Asian Natural Products Research, vol. 3, no. 2, pp. 139144, 2001.

[52] Y. Ogihara and M. Nose, "Novel cleavage of the glycosidic bond of saponins in alcoholic alkali metal solution containing a trace of water," Journal of the Chemical Society, Chemical Communications, no. 18, p. 1417, 1986.

[53] J. Lee, D.-H. Yang, J. H. Suh et al., "Species discrimination of Radix Bupleuri through the simultaneous determination of ten saikosaponins by high performance liquid chromatography with evaporative light scattering detection and electrospray 
ionization mass spectrometry," Journal of Chromatography B: Analytical Technologies in the Biomedical and Life Sciences, vol. 879, no. 32, pp. 3887-3895, 2011.

[54] K. Shimizu, S. Amagaya, and Y. Ogihara, "New derivatives of saikosaponins," Chemical and Pharmaceutical Bulletin, vol. 33, no. 8, pp. 3349-3355, 1985.

[55] R. Tundis, M. Bonesi, B. Deguin et al., "Cytotoxic activity and inhibitory effect on nitric oxide production of triterpene saponins from the roots of Physospermum verticillatum (Waldst \& Kit) (Apiaceae)," Bioorganic and Medicinal Chemistry, vol. 17, no. 13, pp. 4542-4547, 2009.

[56] J. Liu, Y. Fang, L. Yang, X. Qin, G. Du, and X. Gao, "A qualitative, and quantitative determination and pharmacokinetic study of four polyacetylenes from Radix Bupleuri by UPLC-PDA-MS," Journal of Pharmaceutical and Biomedical Analysis, vol. 111, no. 1, pp. 257-265, 2015.

[57] H. Q. Huang, J. Su, X. Zhang, L. Shan, and W. D. Zhang, "Qualitative and quantitative determination of polyacetylenes in different Bupleurum species by high performance liquid chromatography with diode array detector and mass spectrometry," Journal of Chromatography A, vol. 1218, no. 8, pp. 1131-1138, 2011.

[58] Q. C. Li, H. Liang, Y. J Bai et al., "The Chemical Constituents from the Roots of Bupleurum chinense DC," Journal of Chinese Pharmaceutical Sciences, vol. 7, no. 3, pp. 98-99, 1997.

[59] H. Liang, Y. Y. Zhao, and R. Y. Zhang, "A new chromone glycoside from Bupleurum chinense," Chinese Chemical Letters, vol. 9, no. 1, pp. 69-70, 1998.

[60] H. Liang, Y. Zhao, Y. Cui, and Q. Liu, "Flavonoids from the roots of Bupleurum chinense DC," Journal of Beijing Medical University, vol. 7, no. 3, pp. 98-99, 2000.

[61] L. Tan, Y. Y. Zhao, B. Wang et al., "New isoflavonoside from Bupleurum scorzonerifolium," Chinese Chemical Letters, vol. 9, no. 1, pp. 71-73, 1998.

[62] W.-L. Chang, L.-W. Chiu, J.-H. Lai, and H.-C. Lin, "Immunosuppressive flavones and lignans from Bupleurum scorzonerifolium," Phytochemistry, vol. 64, no. 8, pp. 1375-1379, 2003.

[63] M. Kobayashi, T. Tawara, T. Tsuchida, and H. Mitsuhashi, "Studies on the constituents of Umbelliferae plants. XVIII. Minor constituents of Bupleuri Radix: Occurrence of saikogenins, polyhydroxysterols, a trihydroxy C18 fatty acid, a lignan and a new chromone," Chemical and Pharmaceutical Bulletin, vol. 38, no. 11, pp. 3169-3171, 1990.

[64] Q. C. Li, H. Liang, and Y. Y. Zhao, "The chemical constituents from the roots of bupleurum chinense," Journal of Chinese Pharmaceutical Sciences, no. 6, pp. 165-166, 1997.

[65] X. Q. Li, A. H. Song, W. Li X, and K. S. Bi, "Analysis of the fatty acid from Bupleurum chinense DC in China by GC-MS and GC-FID," Chemical \& Pharmaceutical Bulletin, vol. 53, no. 12, pp. 1613-1617, 2006.

[66] J. Y. Xie, "Bupleurum chinense DC polysaccharides attenuates lipopolysaccharide-induced acute lung injury in mice," Phytomedicine International Journal of Phytotherapy \& Phytopharmacology, vol. 19, no. 2, pp. 130-137, 2012.

[67] J. Chun, A. Tosun, and Y. S. Kim, "Anti-inflammatory effect of corymbocoumarin from Seseli gummiferum subsp. corymbosum through suppression of NF- $\kappa$ B signaling pathway and induction of HO-1 expression in LPS-stimulated RAW 264.7 cells," International Immunopharmacology, vol. 31, pp. 207-215, 2016.

[68] J. Zhu, C. Luo, P. Wang, Q. He, J. Zhou, and H. Peng, "Saikosaponin A mediates the inflammatory response by inhibiting the MAPK and NF- $\kappa$ B pathways in LPS-stimulated RAW 264.7 cells," Experimental and Therapeutic Medicine, vol. 5, no. 5, pp. 1345-1350, 2013.

[69] Y. Fu, X. Hu, Y. Cao, Z. Zhang, and N. Zhang, "Saikosaponin a inhibits lipopolysaccharide-oxidative stress and inflammation in Human umbilical vein endothelial cells via preventing TLR4 translocation into lipid rafts," Free Radical Biology and Medicine, no. 89, pp. 777-785, 2015.

[70] T. H. Lee, J. Chang, and B. M. Kim, "Saikosaponin C inhibits lipopolysaccharide-induced apoptosis by suppressing caspase-3 activation and subsequent degradation of focal adhesion kinase in human umbilical vein endothelial cells," Biochemical and Biophysical Research Communications, vol. 445, no. 3, pp. 615621, 2014.

[71] H. Zhao, S. Li, H. Zhang et al., "Saikosaponin a protects against experimental sepsis via inhibition of NOD2-mediated NF- $\kappa \mathrm{B}$ activation," Experimental and Therapeutic Medicine, vol. 10, no. 2, pp. 823-827, 2015.

[72] Y. Kodama, L. Xiaochuan, C. Tsuchiya, Y. Ohizumi, M. Yoshida, and N. Nakahata, "Dual effect of saikogenin D: in vitro inhibition of prostaglandin E 2 production and elevation of intracellular free $\mathrm{Ca}^{2+}$ concentration in C6 rat glioma cells," Planta Medica, vol. 69, no. 8, pp. 765-767, 2003.

[73] P. Li, H. Kawachi, T. Morioka et al., "Suppressive effects of Saireito on monoclonal antibody 1-22-3-induced glomerulonephritis: Analysis of effective components," Pathology International, vol. 47, no. 7, pp. 430-435, 1997.

[74] Y. Chen, X. L. Zhou, and C. R. Xue, "Therapeutic effects and mechanisms of chaihushugan decoction in experimental chronic pancreatitis rats," Chinese Journal of Surgery of Integrated Traditional \& Western Medicine, no. 3, pp. 330-333, 2010.

[75] J. Liu, Z. Zhao, and C. R. Xue, "Effect of chaihu shugan pulvis on dysfunction of pancreatic exocrine secretion in patients with chronic pancreatitis," Chinese Journal of Surgery of Integrated Traditional \& Western Medicine, no. 16, pp. 275-277, 2010.

[76] G. B. Lenon, C. G. Li, C. C. Xue, F. C. K. Thien, and D. F. Story, "Inhibition of inducible nitric oxide production and iNOS protein expression in lipopolysaccharide-stimulated rat aorta and Raw 264.7 macrophages by ethanol extract of a Chinese herbal medicine formula (RCM-101) for allergic rhinitis," Journal of Ethnopharmacology, vol. 116, no. 3, pp. 547-553, 2008.

[77] Y.-L. Cheng, W.-L. Chang, S.-C. Lee et al., "Acetone extract of Bupleurum scorzonerifolium inhibits proliferation of A549 human lung cancer cells via inducing apoptosis and suppressing telomerase activity," Life Sciences, vol. 73, no. 18, pp. 2383-2394, 2003.

[78] Y.-L. Chen, S.-Z. Lin, W.-L. Chang, Y.-L. Cheng, and H.-J. Harn, "Requirement for ERK activation in acetone extract identified from Bupleurrum scorzonerifolium induced A549 tumor cell apoptosis and keratin 8 phosphorylation," Life Sciences, vol. 76, no. 21, pp. 2409-2420, 2005.

[79] Y.-L. Cheng, S.-C. Lee, S.-Z. Lin et al., "Anti-proliferative activity of Bupleurum scrozonerifolium in A549 human lung cancer cells in vitro and in vivo," Cancer Letters, vol. 222, no. 2, pp. 183193, 2005.

[80] Y.-L. Hsu, P.-L. Kuo, T.-C. Weng, M.-H. Yen, L.-C. Chiang, and C.-C. Lin, "The antiproliferative activity of saponin-enriched fraction from Bupleurum kaoi is through Fas-dependent apoptotic pathway in human non-small cell lung cancer A549 cells," Biological and Pharmaceutical Bulletin, vol. 27, no. 7, pp. 11121115, 2004. 
[81] L.-C. Chiang, L. T. Ng, L.-T. Liu, D.-E. Shieh, and C.-C. Lin, "Cytotoxicity and anti-hepatitis B virus activities of saikosaponins from Bupleurum species," Planta Medica, vol. 69, no. 8, pp. 705-709, 2003.

[82] H. L. Hou, S. X. He, Z. F. Zhu et al., ““'The role of saikosaponin $\mathrm{d}$ in regulating HIF-1 $\alpha /$ COX-2 signal transduction pathway in human hepatocellular carcinoma cells," Journal of Xian Jiaotong University, vol. 32, pp. 80-84, 2011.

[83] S. Willimott, J. Barker, L. A. Jones, and E. I. Opara, "An in vitro based investigation of the cytotoxic effect of water extracts of the Chinese herbal remedy LD on cancer cells," Chemistry Central Journal, vol. 3, no. 1, pp. 1-16, 2009.

[84] T. Kuroki, "Prospective study of chemoprevention of hepatocellular carcinoma with sho-saiko-to (TJ-9)," Cancer, vol. 76, no. 5, pp. 743-749, 1995.

[85] H. Y. Zhao, "Clinical observation of the treatment of primary liver cancer by using xiao-chai-hu decoction," Journal of Traditional Chinese Medicine, no. 18, p. 32, 1995.

[86] K. Haranaka, N. Satomi, A. Sakurai, R. Haranaka, N. Okada, and M. Kobayashi, "Antitumor activities and tumor necrosis factor producibility of traditional Chinese medicines and crude drugs," Cancer Immunology Immunotherapy, vol. 20, no. 1, pp. $1-5,1985$.

[87] J.-S. Chang, K.-C. Wang, H.-W. Liu, M.-C. Chen, L.-C. Chiang, and C.-C. Lin, "Sho-saiko-to (Xiao-Chai-Hu-Tang) and crude saikosaponins inhibit Hepatitis B virus in a stable HBVproducing cell line," American Journal of Chinese Medicine, vol. 35, no. 2, pp. 341-351, 2007.

[88] F. Yin, R. Pan, R. Chen, and L. Hu, "Saikosaponins from Bupleurum chinense and inhibition of HBV DNA replication activity," Natural Product Communications, vol. 3, no. 2, pp. 155$157,2008$.

[89] P. W. Cheng, L. T. Ng, L. C. Chiang, and C. C. Lin, "Antiviral effects of saikosaponins on human coronavirus 229E in vitro," Clinical \& Experimental Pharmacology \& Physiology, vol. 33, no. 7, pp. 612-616, 2006.

[90] G. T. Jin, L. Bo, and S. R. Wang, "Experimental study on material basis, efficacy and mechanism of antipyretic effect of Bupleuri Radix," Journal of Chengdu University of Traditional Chinese Medicine, no. 36, pp. 28-30, 2013.

[91] S.-L. Cao, E. Chen, Q.-Z. Zhang, and X.-G. Jiang, "A novel nasal delivery system of a Chinese traditional medicine, Radix bupleuri, based on the concept of ion-activated in situ gel," Archives of Pharmacal Research, vol. 30, no. 8, pp. 1014-1019, 2007.

[92] Y. Xie, W. Lu, S. Cao, X. Jiang, M. Yin, and W. Tang, "Preparation of bupleurum nasal spray and evaluation on its safety and efficacy," Chemical and Pharmaceutical Bulletin, vol. 54, no. 1, pp. 48-53, 2006.

[93] Y. Li, C. Xu, Q. Zhang, J. Y. Liu, and R. X. Tan, "In vitro antiHelicobacter pylori action of 30 Chinese herbal medicines used to treat ulcer diseases," Journal of Ethnopharmacology, vol. 98, no. 3, pp. 329-333, 2005.

[94] Y. Kumazawa, T. Kawakita, H. Takimoto, and K. Nomoto, "Protective effect of saikosaponin a, saikosaponin d and saikogenin D against Pseudomonas aeruginosa infection in mice," International Journal of Immunopharmacology, vol. 12, no. 5, pp. 531-537, 1990

[95] X. M. Du, H. Xie, and Y. Kang, "The Pharmacological activity of chinese "chaihu"-the root of bupleurum species," Sci Eval Clin Appl, no. 10, pp. 135-149, 2006.
[96] Z.-Y. Li, H.-M. Sun, J. Xing, X.-M. Qin, and G.-H. Du, "Chemical and biological comparison of raw and vinegar-baked Radix Bupleuri," Journal of Ethnopharmacology, vol. 165, pp. 2028, 2015.

[97] H. Abe, M. Sakaguchi, M. Yamada, S. Arichi, and S. Odashima, "Pharmacological actions of saikosaponins isolated from Bupleurum falcatum. I. Effects of saikosaponings on liver function," Planta Medica, vol. 40, no. 4, pp. 366-372, 1980.

[98] H. Matsuda, T. Murakami, K. Ninomiya, M. Inadzuki, and M. Yoshikawa, "New hepatoprotective saponins, bupleurosides III, VI, IX, and XIII, from Chinese Bupleuri Radix: Structurerequirements for the cytoprotective activity in primary cultured rat hepatocytes," Bioorganic \& Medicinal Chemistry Letters, vol. 28, no. 52, pp. 2193-2198, 1997.

[99] X. H. Han, X. D. Gai, Y. J. Xue, and M. Chen, "Effects of the extracts from Bupleurum Chinese DC on intracelluar free calcium concentration and vincristine accumulation in human hepatoma BEL-7402 cells," Tumor, no. 26, pp. 314-317, 2006.

[100] H. Abe, M. Sakaguchi, S. Odashima, and S. Arichi, "Protective effect of saikosaponin-d isolated from Bupleurum falcatum L. on CCl4-induced liver injury in the rat," Naunyn-Schmiedeberg's Archives of Pharmacology, vol. 320, no. 3, pp. 266-271, 1982.

[101] J. Fan, X. Li, P. Li et al., "Saikosaponin-d attenuates the development of liver fibrosis by preventing hepatocyte injury," Biochemistry \& Cell Biology, vol. 85, no. 2, pp. 189-195, 2007.

[102] M. Yamakage, J.-I. Hattori, J.-I. Satoh, and A. Namiki, "Effects of the Chinese herbal medicines Bupleuri radix, Ginseng radix, and Zingiberis rhizoma on lymphatic vessel activity in rats," American Journal of Chinese Medicine, vol. 34, no. 6, pp. 10631068,2006

[103] Y. Kumazawa, H. Takimoto, C. Nishimura, T. Kawakita, and K. Nomoto, "Activation of murine peritoneal macrophages by saikosaponin a, saikosaponin d and saikogenin d," International Journal of Immunopharmacology, vol. 11, no. 1, pp. 21-28, 1989.

[104] M. Kato, M.-Y. Pu, K.-I. Isobe, T. Hattori, N. Yanagita, and I. Nakashima, "Cell type-oriented differential modulatory actions of saikosaponin-d on growth responses and DNA fragmentation of lymphocytes triggered by receptor-mediated and receptor-bypassed pathways," Immunopharmacology, vol. 29, no. 3, pp. 207-213, 1995.

[105] M. Kato, M.-Y. Pu, K.-I. Isobe et al., "Characterization of the immunoregulatory action of saikosaponin-d," Cellular Immunology, vol. 159, no. 1, pp. 15-25, 1994.

[106] V. K. W. Wong, H. Zhou, S. S. F. Cheung, T. Li, and L. Liu, "Mechanistic study of saikosaponin-d (Ssd) on suppression of murine T lymphocyte activation," Journal of Cellular Biochemistry, vol. 107, no. 2, pp. 303-315, 2009.

[107] H. Yi, B. Long, X. Ye, L. Zhang, X. Liu, and C. Zhang, "Autophagy: A potential target for thyroid cancer therapy (Review)," Molecular and Clinical Oncology, vol. 2, no. 5, pp. 661-665, 2014.

[108] N. Mizushima, "Autophagy: process and function," Genes \& Development, vol. 21, no. 22, pp. 2861-2873, 2007.

[109] D. C. Rubinsztein, P. Codogno, and B. Levine, "Autophagy modulation as a potential therapeutic target for diverse diseases," Nature Reviews Drug Discovery, vol. 11, no. 9, pp. 709-730, 2012.

[110] Z. J. Yang, C. E. Chee, S. Huang, and F. A. Sinicrope, "The role of autophagy in cancer: therapeutic implications," Molecular Cancer Therapeutics, vol. 10, no. 9, pp. 1533-1541, 2011.

[111] E.-L. Eskelinen, "The dual role of autophagy in cancer," Current Opinion in Pharmacology, vol. 11, no. 4, pp. 294-300, 2011. 
[112] O. Yamaguchi and K. Otsu, "Role of autophagy in aging," Journal of Cardiovascular Pharmacology, vol. 60, no. 3, pp. 242247, 2012.

[113] B. Y. Law, J. F. Mo, and V. K. Wong, "Autophagic effects of Chaihu (dried roots of Bupleurum Chinense DC or Bupleurum scorzoneraefolium WILD)," Chinese Medicine, vol. 9, no. 1, article 21, 2014.

[114] Y. Cheng, Y. Huang, Y. Tian, L. Xu, G. Q. Liu, and Z. J. Zahng, "Assessment of the effects of Radix Bupleuri and vinegarbaked Radix Bupleuri on cytochrome 450 activity by a six-drug cocktail approach," Chinese Journal of Natural Medicines, vol. 11, no. 3, pp. 302-308, 2013.

[115] X. Chen, T. Yu, Z. Chen, R. Zhao, and S. Mao, "Effect of saikosaponins and extracts of vinegar-baked Bupleuri Radix on the activity of $\beta$-glucuronidase," Xenobiotica, vol. 44, no. 9, pp. 785-791, 2014.

[116] M. Ye, Y.-F. Bi, L. Ding, W.-W. Zhu, and W. Gao, "Saikosaponin a functions as anti-epileptic effect in pentylenetetrazol induced rats through inhibiting mTOR signaling pathway," Biomedicine and Pharmacotherapy, vol. 81, pp. 281-287, 2016.

[117] D. He, H. Wang, L. Xu et al., "Saikosaponin-a Attenuates Oxidized LDL Uptake and Prompts Cholesterol Efflux in THP1 Cells," Journal of Cardiovascular Pharmacology, vol. 67, no. 6, pp. 510-518, 2016.

[118] K.-G. Shyu, S.-C. Tsai, B.-W. Wang, Y.-C. Liu, and C.-C. Lee, "Saikosaponin C induces endothelial cells growth, migration and capillary tube formation," Life Sciences, vol. 76, no. 7, pp. 813-826, 2004.

[119] T. H. Lee, S. H. Park, M.-H. You, J.-H. Lim, S.-H. Min, and B. M. Kim, "A potential therapeutic effect of saikosaponin $\mathrm{C}$ as a novel dual-target anti-Alzheimer agent," Journal of Neurochemistry, vol. 136, no. 6, pp. 1232-1245, 2016.

[120] S. Zhu, F. Ling, Q. Zhang et al., "Anthelmintic activity of saikosaponins a and $\mathrm{d}$ from radix bupleuri against Dactylogyrus spp. infecting goldfish," Diseases of Aquatic Organisms, vol. 111, no. 2, pp. 177-182, 2014.

[121] S. C. Cui, Q. Z. Cao, and C. X. Su, "Analysis of 50 cases of druginduced liver disease," Journal of Capital Medicine University, vol. 20, pp. 296-297, 1999.

[122] D. C. H. Teo, P. S. L. Ng, S. H. Tan et al., "Drug-induced liver injury associated with Complementary and Alternative Medicine: A review of adverse event reports in an Asian community from 2009 to 2014," BMC Complementary and Alternative Medicine, vol. 16, no. 1, pp. 1-11, 2016.

[123] S. Itoh, K. Marutani, T. Nishijima, S. Matsuo, and M. Itabashi, "Liver injuries induced by herbal medicine, Syo-saiko-to (xiaochai-hu-tang)," Digestive Diseases and Sciences, vol. 40, no. 8, pp. 1845-1848, 1995.

[124] C.-H. Lee, J.-D. Wang, and P.-C. Chen, "Risk of Liver Injury Associated with Chinese Herbal Products Containing Radix bupleuri in 639, 779 Patients with Hepatitis B Virus Infection," PLoS ONE, vol. 6, no. 1, Article ID e16064, 2011.

[125] R. Sun, L. Wang, Q. Yang, W. Huang, and L. L. Lv, "Acute toxicity of volatile oil from Bupleurum chinense in rats and mice," Chinese Journal of Experimental Traditional Medical Formulae, vol. 16, pp. 154-156, 2010.

[126] W. Huang, R. Sun, and Z. Zhang, “"Dose-time-toxicity” relationship study on hepatotoxicity caused by multiple dose of total Bupleurum saponin crude extracts to rats," China Journal of Chinese Materia Medica, vol. 35, no. 35, pp. 3344-3347, 2010.

[127] L. Xu, R. Song, J.-X. Tian, Y. Tian, G.-Q. Liu, and Z.-J. Zhang, "Analysis of saikosaponins in rat plasma by anionic adducts-based liquid chromatography tandem mass spectrometry method," Biomedical Chromatography, vol. 26, no. 7, pp. 808-815, 2012.

[128] L. Lin, B. Ni, H. Lin et al., "Traditional usages, botany, phytochemistry, pharmacology and toxicology of Polygonum multiflorum Thunb.: a review," Journal of Ethnopharmacology, vol. 159, pp. 158-183, 2015. 

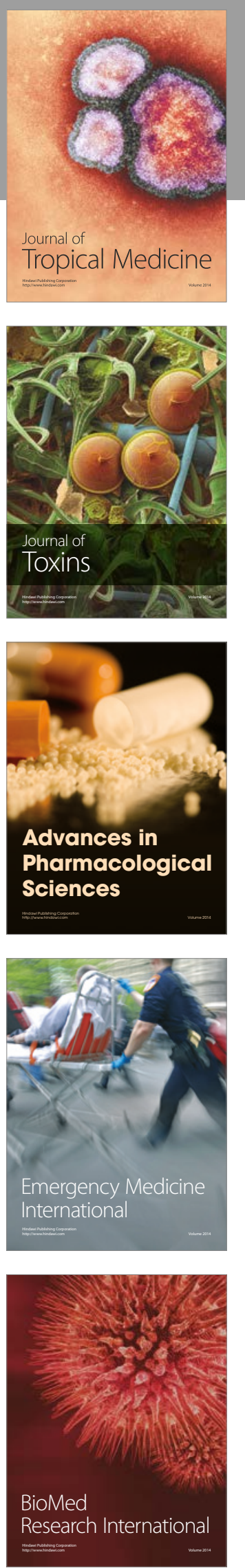
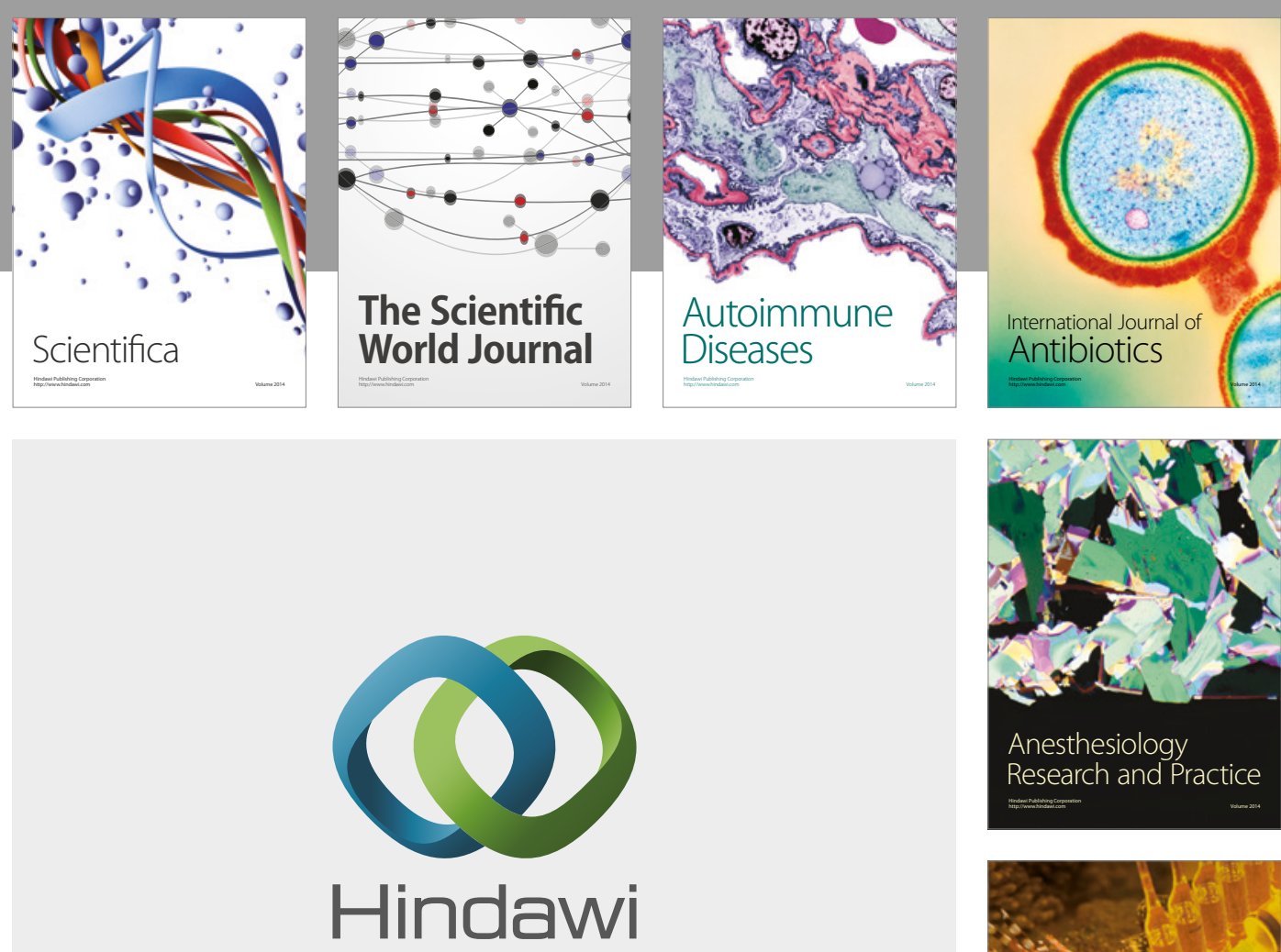

Submit your manuscripts at

https://www.hindawi.com
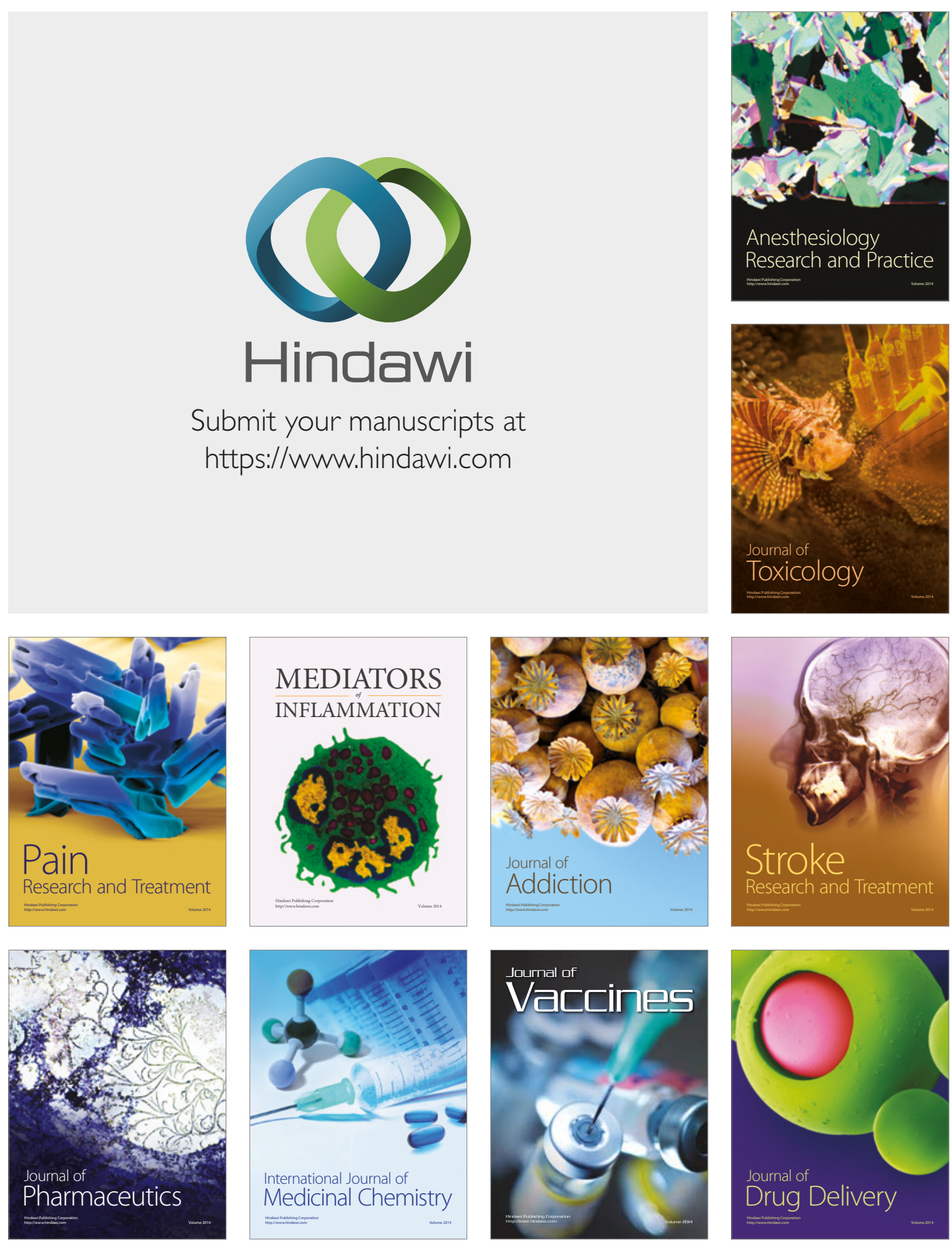